\title{
COMPARATIVE LIFE CYCLE ASSESSMENT OF EDIBLE VEGETABLE FRYING OILS
}

\author{
Valentina Prado ${ }^{1,2, *}$, Jesse Daystar ${ }^{3}$, Steven Pires ${ }^{3}$, Michele Wallace ${ }^{3}$, Lise Laurin ${ }^{1}$ \\ ${ }^{1}$ EarthShift Global LLC, Kittery, Maine, USA. \\ 2 Faculty of Management, Los Andes University, Bogotá, Colombia. \\ ${ }^{3}$ Cotton Incorporated, Cary, North Carolina, USA. \\ * Correspondence: v.prado@uniandes.edu.co.
}

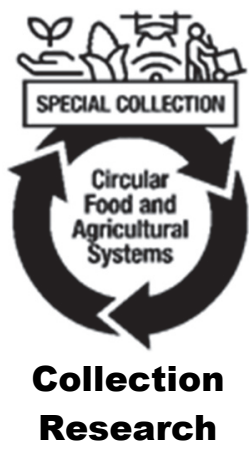

\section{Highlights}

- Cottonseed oil (CSO), a cotton byproduct, has advantages for climate change compared to other seed oils.

- Results show that the cultivation phase is the main impact driver for all vegetable oils analyzed in this study.

- Refined CSO (U.S.) can reduce climate change impacts by up to $83 \%$ as compared to the other oils analyzed.

ABSTRACT. Edible vegetable oils are a major source of climate change impacts and an environmental concern in the processed food industry. This study consists of a cradle-to-grave life cycle assessment (LCA) of refined U.S. cottonseed oil (CSO), global soybean oil, U.S. canola oil, and palm oil sourced from Indonesia and Malaysia. Considering the oils equivalent for deep frying, they are compared on a $1 \mathrm{~kg}$ of oil basis. Analysis includes sensitivity analyses for modeling allocation choices and oil mixes as well as uncertainty analysis. Results show that the cultivation phase is the main impact driver for all vegetable oils analyzed, which favors CSO (U.S.) because it is a co-product. Refined CSO (U.S.) can reduce climate change impacts by up to $83 \%$. Overall, refined CSO (U.S.) was a top performer in six of the eight impact categories evaluated. When ranking the oils, refined CSO (U.S.) was the preferred choice. Despite being the preferred choice, there are tradeoffs with CSO, such as water scarcity. In the context of global-scale commercial frying applications, e.g., McDonald's daily French fry production of 9 million tons per day, switching the frying oil to refined CSO (U.S.) represents potential savings of 1,130 to 2,188 tons of $\mathrm{CO}_{2}-e q d^{-1}$. For fast-food chains seeking to reduce their climate change impacts, refined CSO (U.S.) may be useful in frying applications. However, opportunities may exist for improvement in water use efficiency in the cultivation phase, which reinforces the need for continuous improvements in agriculture.

Keywords. Comparative life cycle assessment, Canola oil, Cottonseed oil, Cotton sustainability, Fast-food industry, LCA, Palm oil, Soybean oil, Vegetable frying oils.

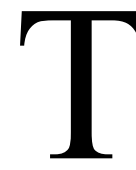
The global food supply chain emitted roughly $13.6 \mathrm{Gt}$ of $\mathrm{CO}_{2}$-eq year-1 ${ }^{-1}$ or $26 \%$ of global anthropogenic greenhouse gas (GHG) emissions in 2018 (Mouron et al., 2016; Ritche, 2019). Food processing accounted for $4 \%$ (544 Mt) of this total, making reduction of GHG emissions in food processing of considerable interest. A 2019 report noted that an investor group managing \$6.5 trillion called on the world's largest fast-food restaurant chains to reduce GHG emissions and water use (Win, 2019). Most major fast-food chains have committed to $\mathrm{GHG}$ emission reductions. McDonald's has a goal of $36 \%$

\footnotetext{
(1) $\$$ The authors have paid for open access for this article. This work is licensed under a Creative Commons AttributionNonCommercial-NoDerivatives 4.0 International License https:/creative commons.org/licenses/by-nc-nd/4.0/

Submitted for review on 2 February 2021 as manuscript number NRES 14515; approved for publication as a Research Article and as part of the Circular Food and Agricultural Systems Collection by the Natural Resources \& Environmental Systems Community of ASABE on 7 June 2021.
}

reduction in $\mathrm{GHG}$ emissions from its restaurants and offices by 2030 (Golden, 2019), and other fast-food chains have either established goals for GHG emission cuts or have plans to do so in the near future (RBI, 2020; NRA, 2017).

Edible vegetable oils, primarily from rapeseed, soybean, and palm oil, are widely used in commercial food processing, and their production has more than doubled in the past 20 years due to growing demand in the food industry and increasingly the biofuel sector (Mielke, 2017). In the energy sector, vegetable oils are intended to be a less carbonintensive alternative to fossil fuels, but in some instances crop production for the main commodity vegetable oils has been controversial due to environmental impacts from deforestation and indirect land use changes (Bai et al., 2021; Fassler, 2016; Hunsberger et al., 2017; Jia et al., 2020). Acknowledging the increasing demand for these oilseed crops, it becomes important to understand their life cycle environmental impacts and in this way inform the food processing industry about how the choice of vegetable frying oil can 
support environmental targets, with a focus on GHG reduction targets.

One very large application of vegetable frying oil is the production of French fries for retail sale and food service, which reached a market value of \$20.4 billion in 2018 (Research and Markets, 2019). Given the scale of fried food production and sales, French fry production contributes significant GHG emissions via the deep-frying process, which uses heated vegetable oils or oil mixtures (Mouron et al., 2016). A comparative analysis of the climate change impacts of the different vegetable oils used in deep frying is therefore timely and important.

Previous studies have explored the life cycle impacts of vegetable frying oils (Khatri and Jain, 2017; Mouron et al., 2016; Schmidt, 2010, 2015), and different oils and oil mixtures have different life cycle impacts. For instance, Schmidt (2010) presented a comparative life cycle assessment (LCA) of palm oil and rapeseed oil for the EU market and found that palm oil performed better than rapeseed oil in all categories except global warming, biodiversity, and ecotoxicity. A further study (Schmidt, 2015) compared five vegetable oils (palm oil, soybean oil, rapeseed oil, sunflower oil, and peanut oil) using system expansion and found that rapeseed oil had lower climate change impacts compared to soybean oil and palm oil. In terms of water scarcity, palm oil and soybean oil had more preferable performances. Schmidt (2015) also evaluated the results with and without biogenic carbon and indirect land use changes, and the relative performances of the oils remained unchanged. Overall, previous studies agree that the cultivation phase is a key contributor to the life cycle impacts of vegetable frying oils; however, to date, no studies have included cottonseed oil in their comparative analyses. Cottonseed oil may have advantages compared to commodity vegetable frying oil alternatives because it is a byproduct of cotton lint production and the life cycle impacts of cotton cultivation are split between cotton lint (for textiles) and cotton seed (for oil).

Cottonseed oil has long been used as a cooking oil in the U.S. (O'Brien, 2002), although it has more recently lost market dominance to soybean oil. This study presents a comparative LCA evaluation of the potential for life cycle GHG (and other) impact reductions through the use of edible cottonseed oil for frying in comparison to commodity vegetable oils.

\section{METHODS}

\section{GOAL AND SCOPE}

This study complies with ISO 14044:2006. System modeling used the LCA software SimaPro (PRé Sustainability, 2021) to perform life cycle inventories and impact assessments, contribution analyses, parameterization, and related sensitivity analyses and uncertainty analyses. The goal of this study was to understand the life cycle environmental impacts (with an emphasis on climate change impacts) of U.S. refined cottonseed oil in comparison to conventional vegetable oils for high-temperature frying. This comparison used a functional unit of $1 \mathrm{~kg}$ of vegetable frying oil at the refinery gate with cradle-to-grave system boundaries (fig. 1).

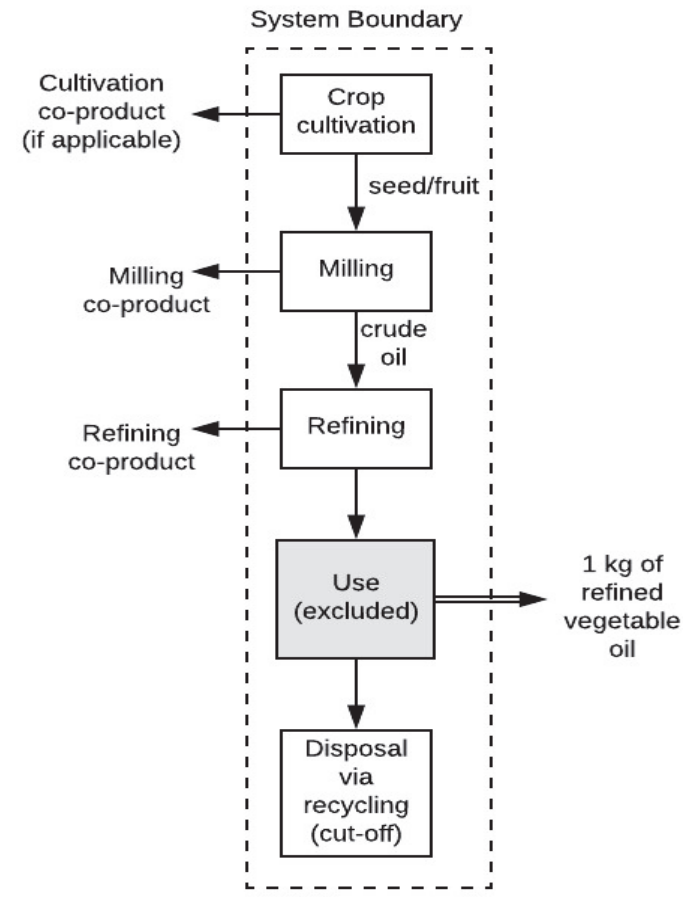

Figure 1. Flowchart for refined vegetable oils, cradle-to-grave.

A secondary goal was to communicate the relevancy of these results in connection to a common frying application, i.e., fast-food French fries, and what this means for French fry consumption at a global or per capita scale. A secondary functional unit was used to evaluate the amount of frying oil required for $1 \mathrm{~kg}$ of French fries at a fast-food restaurant, which corresponds to $0.1 \mathrm{~kg}$ of frying oil (see Appendix B for calculation of the frying oil amount).

This study considered the following refined oils:

- U.S.-sourced cottonseed oil, referred to here as refined CSO (U.S.).

- A mix of Indonesian (67\%) and Malaysian (33\%) palm oils ( $>90 \%$ of the global production of palm oil; Beroe, 2019), referred to as palm (ID/MY).

- High-oleic globally sourced soybean oil, referred to as soybean (GLO).

- High-oleic U.S.-sourced canola, referred to as canola (U.S.).

- McDonald's representative oil mix, referred to as canola/corn/soybean.

- Wendy's representative oil mix, referred to as soybean/corn/CSO.

- Burger King's representative oil mix, referred to as canola/palm.

Because the compositions of the oil mixes are not publicly disclosed and vary with market prices, this comparative study assumed an even mix as a representative case and included an uncertainty analysis so that cottonseed oil could be compared to a variety of formulations. The impact assessment method used in this study followed the combination of indicators selected in the latest global cotton LCA (Cotton Incorporated, 2018) (table 1). 
Table 1. Midpoint indicators selected.

\begin{tabular}{|c|c|c|}
\hline Indicator and Unit & Symbol & Impact Assessment Method \\
\hline $\begin{array}{l}\text { Global warming } \\
\left(\mathrm{kg} \mathrm{CO}_{2} \text {-eq }\right)\end{array}$ & GW & $\begin{array}{c}\text { IPCC, } 2007 \\
\text { (biogenic flows not included) }\end{array}$ \\
\hline $\begin{array}{l}\text { Abiotic depletion } \\
(\mathrm{kg} \mathrm{Sb}-\mathrm{eq})\end{array}$ & $\mathrm{AB}$ & $\begin{array}{c}\text { CML-IA } \\
\text { (Sleeswijk et al., 2008) }\end{array}$ \\
\hline $\begin{array}{l}\text { Eutrophication } \\
\left(\mathrm{kg} \mathrm{PO}_{4}-\mathrm{eq}\right)\end{array}$ & EUT & CML-IA \\
\hline $\begin{array}{l}\text { Acidification } \\
\left(\mathrm{kg} \mathrm{SO}_{2}-\mathrm{eq}\right)\end{array}$ & $\mathrm{ACD}$ & CML-IA \\
\hline $\begin{array}{l}\text { Photochemical oxidation } \\
\qquad\left(\mathrm{kg} \mathrm{C}_{2} \mathrm{H}_{4}\right)\end{array}$ & PO & CML-IA \\
\hline $\begin{array}{l}\text { Fine particulate matter } \\
\text { (kg PM 2.5-eq) }\end{array}$ & FPM & $\begin{array}{c}\text { ReCiPe Midpoint } 2016 \\
\text { (Hierarchist) } \\
\text { (Huijbregts, 2017) }\end{array}$ \\
\hline $\begin{array}{l}\text { Ozone layer depletion } \\
(\mathrm{kg} \text { CFC-11-eq) }\end{array}$ & OLD & CML-IA \\
\hline $\begin{array}{l}\text { Water scarcity } \\
\left(\mathrm{m}^{3}\right)\end{array}$ & WAT & $\begin{array}{c}\text { AWARE } \\
\text { (Boulay et al., 2018) }\end{array}$ \\
\hline
\end{tabular}

\section{SENSITIVITY}

Sensitivity analysis in this study was used to explore the robustness of the assumptions and evaluate the aspects found to most influence the results. Sensitivity analyses test the effects of allocation, which is an important modeling choice for the cottonseed oil system. Most cotton LCA studies apply an economic allocation approach because it reflects the economic drivers associated with cotton cultivation, with most of the burden allocated to cotton lint because lint drives most of the associated revenue. Therefore, for this study's baseline, the allocation of co-products was done on an economic basis that allocated $16 \%$ of the cultivation impacts to cottonseed (table A1 in Appendix A). Nevertheless, massbased allocation was evaluated for completeness (which allocated $58 \%$ of the cultivation impacts to cottonseed) and was included as a sensitivity analysis to test alternative economic partitioning coefficients, given market fluctuations. Partitioning factors for cottonseed and cottonseed oil in the cultivation and refining phases are provided in table A1 in Appendix A.

\section{LIFE CYCLE INVENTORY}

In addition, acknowledging that commercial vegetable frying oil mixes are highly variable, depending on the price and availability of oils, this study evaluated the environmental performance of these oil mixes by stochastically varying the proportions of the base oils in the mixes.

The inventory for vegetable oils came from the Ecoinvent version 3.5 database (Wernet et al., 2016). The inventory for U.S. cotton cultivation was derived from the World Apparel and Footwear Life Cycle Database (WALDB) (Quantis, 2018), with data on CSO milling and refining sourced from Ecoinvent version 3.5. The inventory for the other oils was taken from Ecoinvent, except for the addition of data for milling and refining operations where required. A description of the inventory for the refined oils is provided in table A2 in Appendix A. Transportation is included in the Ecoinvent processes to account for distribution in the supply chain all the way to the refinery, where additional transport processes are added to account for a global average distribution. Therefore, the transport impacts are embedded in each process.

\section{DATA QUALITY, UNCERTAINTY, AND RANKING}

The default data quality indicators (DQI) implemented in Ecoinvent were used to assess each flow in a data quality matrix approach. Six types of DQI were evaluated by the chosen pedigree matrix (Frischknecht et al., 2007; Weidema et al., 2013) using scores from 1 to 5 for six quality parameters: reliability, completeness, temporal correlation, geographic correlation, technological correlation, and sample size.

These scores translate the quality coefficients into a standard deviation for a lognormal distribution, which allows the quantification of uncertainties for each inventory where the pedigree matrix is applied. Inventory uncertainties from the pedigree matrix were propagated to midpoint results using 1,000 Monte Carlo runs. A discernibility analysis (Heijungs and Kleijn, 2001) was applied to the results of the uncertainty analysis of the global warming category to evaluate, per run, the number of times one alternative was larger than another. This was done by subtracting one value from the other and counting the number of times there was a negative or positive result. When this value reached $95 \%$ of the runs or higher, the alternatives were considered statistically different. Thus, the alternative with the smallest mean (lowest impact) can be considered superior despite the uncertainties. The discernibility analysis does not consider the magnitude of a difference; rather, it applies a smaller/larger dichotomy. Thus, two alternatives may have close values for the computed impact metric yet still be considered statistically discernible.

Given the uncertainty in the comparative analysis of the vegetable frying oils, this study applied a method for the evaluation of tradeoffs based on the mutual uncertainties to identify where the different oils had the greatest differences. The aim was to illustrate the comparative results in the context of uncertainties and in this way to identify the aspects with the least and greatest uncertainties (Mendoza Beltran et al., 2018; Prado-Lopez et al., 2016). The aspects with uncertainties that differ the most among alternatives are often the aspects for which a particular decision is most relevant. Where aspects are similar among alternatives, a decision to select a certain system has less impact. Our approach used uncertainties to support identification of relevant aspects based on data uncertainty; it did not apply weighting or seek to aggregate the results.

An additional interpretative aid used in this study was stochastic multi-attribute analysis (SMAA; Prado and Heijungs, 2018), which is a method used to help resolve tradeoffs in comparative LCAs. SMAA enables a partial ranking of alternatives if provided uncertainties at midpoints and a stochastic sampling of weights (meaning no single perspective is favored, and analysis shows the likelihood of ranks given this variability). SMAA has been used previously in comparative LCAs, as shown by a variety of applications (Canis et al., 2010; Prado-Lopez et al., 2014; Prado et al., 2012, 2019; Rajagopalan et al., 2016). This method generates a probabilistic ranking based on the results of the uncertainty analysis. The probabilistic ranking is the probability of each alternative to occupy a certain rank. The rank means the overall preferability, so that the alternative in the first rank can be considered the best compromise. On the 
other hand, if an alternative ranks last, its environmental performance is poor compared to the other alternatives. Appendix $\mathrm{C}$ provides a detailed description of the data quality elements used for the vegetable frying oil systems.

\section{RESULTS}

This section includes the results of the impact assessment in terms of the contribution and comparative analysis. The corresponding data tables are included in Appendix D.

\section{CONTRIBUTION ANALYSIS}

Figure 2 shows the contribution analysis of the four vegetable frying oils that were analyzed in this study. One clear trend is that cultivation is the largest overall contributor for all the seed oil systems, and refining and milling contributed uniquely to different impact categories across the oils considered. The transportation processes embedded in each phase of the vegetable oil supply chains contributed a minimal portion of the impacts. The contribution of milling to photochemical oxidation was greater across the oil systems, and this was due to the wastewater treatment process. Refining impacts were most accentuated in ozone layer depletion

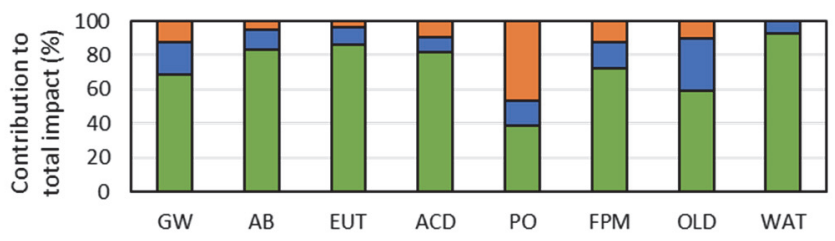

a) Refined CSO (US)

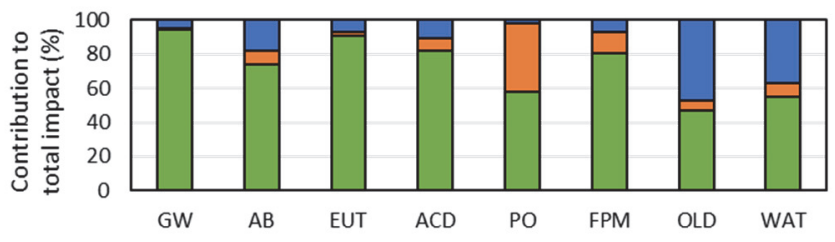

b) Palm (ID/MY)
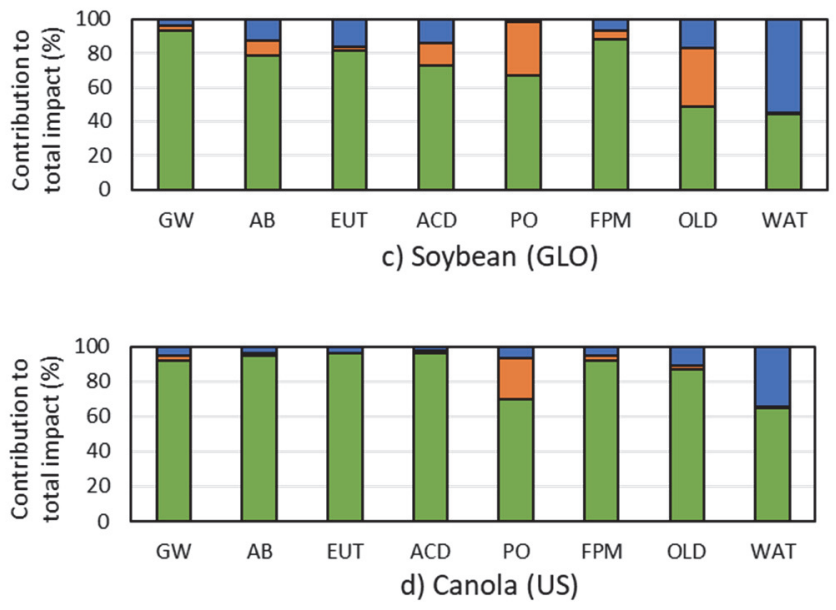

$\square$ Cultivation $\square$ Milling $\square$ Refining

Figure 2. Contribution analyses for different refined vegetable oils. Data tables can be found in Appendix D. and water scarcity, and this was due to transportation and water use.

\section{Comparative ANALYsis}

Comparative analyses of the climate change impacts of the vegetable oils on a $1 \mathrm{~kg}$ basis showed that refined CSO (U.S.) had the lowest impact and soybean (GLO) had the highest impact (fig. 3), driven mostly by differences in cultivation impacts. Figure 3 includes the uncertainties that were propagated from the background inventory, which helps illustrate how refined CSO (U.S.) had a lower impact than the other seed oils considered, even when accounting for uncertainties. This lower impact is consistent with the fact that refined CSO (U.S.) is a byproduct of cotton lint cultivation. Cultivation impacts are the main driver of environmental impacts overall, as shown in the contribution analysis (fig. 2). Climate change impacts for the oil mixes, refined palm (ID and MY), and refined canola (U.S.) lie between those of refined CSO (U.S.) and soybean (GLO). A discernibility analysis of refined CSO (U.S.) with respect to the other oils and mixes found that refined CSO (U.S.) was discernible from the other vegetable oil systems in at least $95 \%$ of the Monte Carlo runs, meaning that the higher reduction in climate change impacts for refined CSO (U.S.) is statistically significant (data tables for the comparative analysis are provided in Appendix D).

These results apply to the specific data that were used, and the results of the discernibility analysis can change with scope because of the variability in agricultural practices across geographic areas. Nonetheless, the results for the climate change impacts in this study are comparable with other studies despite some differences in the modeling. For instance, Ferreira Lima et al. (2017) estimated approximately $1.0 \mathrm{~kg} \mathrm{CO}_{2}$-eq kg-1 $\mathrm{CSO}$ when considering economic allocation, compared with the result of $1.1 \mathrm{~kg} \mathrm{CO}_{2}$-eq kg-1 $\mathrm{CSO}$ (U.S.) in this study. Estimates in the literature for palm oil were mostly derived from the same markets used here (Malaysia and Indonesia) and resulted in carbon footprints ranging between 2.5 and $4.8 \mathrm{~kg} \mathrm{CO}_{2}$-eq kg${ }^{-1}$ palm oil (Schmidt, 2010, 2015), compared with the results of $4.8 \mathrm{~kg} \mathrm{CO}_{2}$-eq kg-1 palm oil in this study. The carbon footprint for canola oil ranged between 2.2 and $3.1 \mathrm{~kg} \mathrm{CO}_{2}$-eq kg${ }^{-1}$ oil, and this study calculated a median value of $3.8 \mathrm{~kg} \mathrm{CO}_{2}$-eq kg-1 oil. Finally, this study calculated a median value for soybean oil of $6.4 \mathrm{~kg}$ $\mathrm{CO}_{2}$-eq kg ${ }^{-1}$, while previous studies estimated a range of 3.0 to $9.0 \mathrm{~kg} \mathrm{CO}_{2}$-eq kg-1 oil (Panichelli et al., 2009; Schmidt, 2015).

To place the climate change results in context, it is estimated that $0.1 \mathrm{~kg}$ of vegetable oil is used during the frying process per $\mathrm{kg}$ of French fries (Appendix B). Given that many fast-food chains have set carbon reduction targets, we can use the results of this study to run scenarios to determine the magnitude of the GHG reduction associated with switching to refined CSO (U.S.) from each of the other seed oils considered in this study. In general, if a fast-food chain switched to refined CSO (U.S.) for its frying applications, the resulting reduction in climate change impacts would be significant. If a fast-food chain switched to refined CSO (U.S.) from soybean (GLO), the GHG impact would be reduced by $83 \%$, switching to refined CSO (U.S.) from palm 


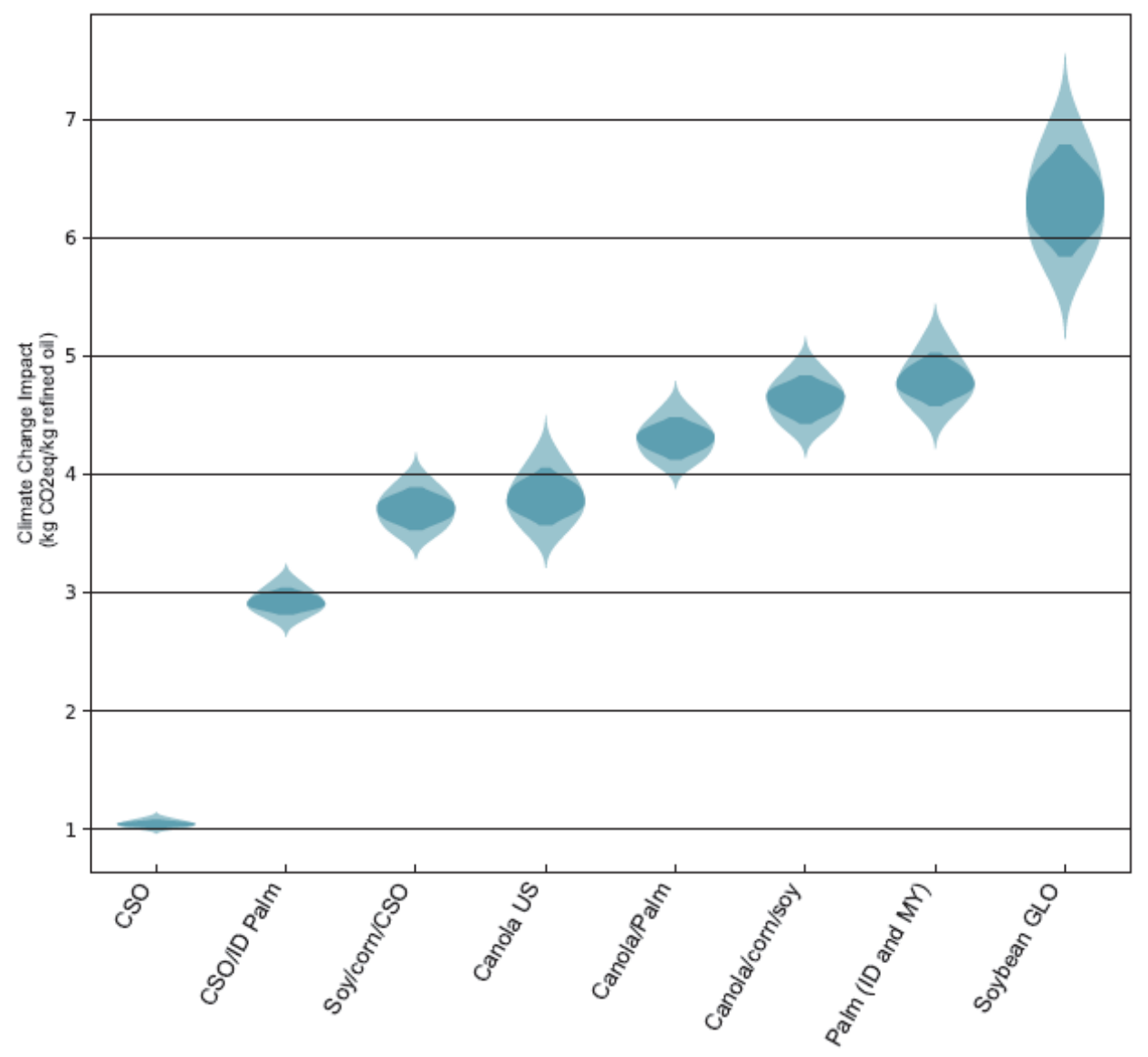

Figure 3. Violin plots of climate change impacts of $1 \mathrm{~kg}$ of refined oil with uncertainty. The result has a $50 \%$ probability of occurring in the darker area, with the width indicating higher probability. The full violin indicates a $95 \%$ probability.

(ID and MY) reduces the GHG impact by $78 \%$, and switching to refined CSO (U.S.) from canola (U.S.) reduces the GHG impact by $72 \%$.

This leads to an absolute reduction of 0.27 to $0.53 \mathrm{~kg} \mathrm{CO}_{2}$ $\mathrm{kg}^{-1}$ French fries when considering a change to refined CSO (U.S.) from the other single-source oils (not mixes). Extrapolating these reductions to the estimated 9 million $\mathrm{lb}$ (4 million $\mathrm{kg}$ ) of French fries that a chain like McDonald's sells every day (Mueller, 2020) provides a substantial GHG emission reduction potential, ranging from 1,130 to 2,188 tons of $\mathrm{CO}_{2}$ per day. In this example, switching to refined $\mathrm{CSO}$ (U.S.) can reduce GHG emissions equivalent to the annual energy consumption of 130 to 252 U.S. homes each day, or 47,450 to 91,980 homes per year (EPA, 2020). When considering the individual consumer and the estimated $29 \mathrm{lb}$ $(13 \mathrm{~kg})$ of French fries that the average American consumes each year (Rupp, 2015), a switch in the frying oil can lead to savings of 3.6 to $7.0 \mathrm{~kg}$ of $\mathrm{CO}_{2}$ per year per average American consumer. This information can support fast-food chains' carbon reduction targets.

Note that these estimates provide an indication of the potential climate change impact; the actual impacts of switching between oils must be studied in each case. In addition, although previous research suggests that both the frying quality and flavor profile of cottonseed oil is favorable to consumers (List, 2016), this study did not consider differences in product quality or sensory perception by the consumer.
In addition to climate change, this study evaluated seven other impact categories. To ease interpretation, the comparative results for these seven impact categories are divided into water-related impacts, resource-related impacts, and airrelated impacts. Starting with water-related impacts (fig. 4), canola oil had the largest impact in eutrophication, about twice as much as the other oils. Eutrophication in this context is due to runoff of fertilizers from fields to surrounding water bodies. Acidification (fig. 4) shows roughly the same pattern as eutrophication, with canola oil and its mixes showing higher impacts, and is driven by unmanaged runoff of nitrogen-bearing fertilizers.

Water scarcity evaluates the cumulative water use throughout the life cycle and provides a measure of water use with respect to water availability. For example, $1 \mathrm{~m}^{3}$ of water used in an arid region can have a higher water scarcity result than the same $1 \mathrm{~m}^{3}$ of water used in a region with higher water availability. Refined CSO (U.S.) and its mixes had the largest water scarcity impacts. This represents a tradeoff for cotton and is consistent with the fact that cotton, as a drought-resistant crop, is cultivated in areas with high water stress where other crops cannot grow; therefore, irrigation water use in these areas may lead to a higher water scarcity result. Any interpretation of the water use results must consider that the average coefficient of variation for water scarcity is 50 times larger than for the impact category with the second largest coefficient of variation, meaning that there are high uncertainties in the inventory related to water. 


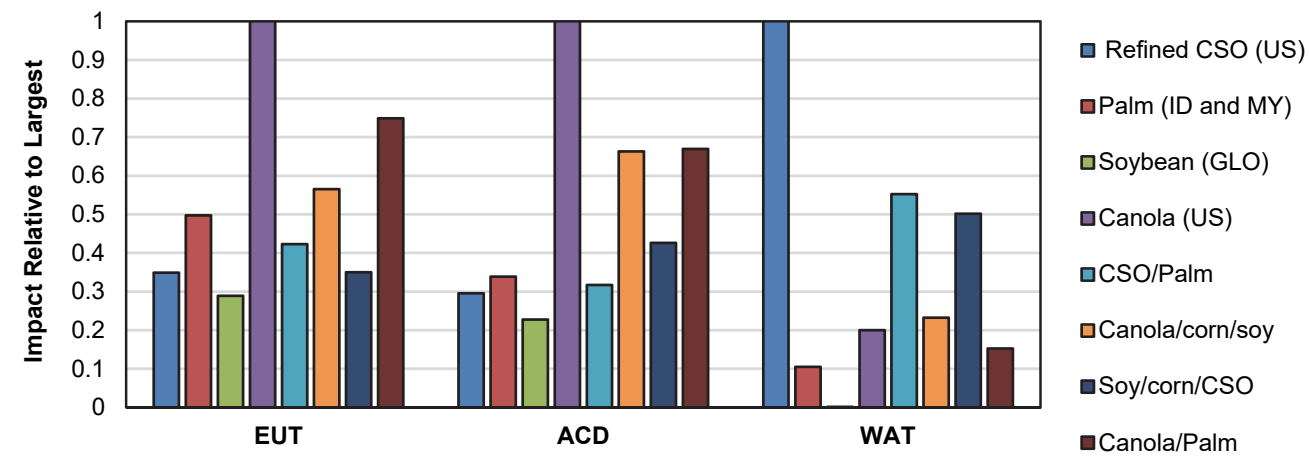

Figure 4. Comparative analysis of vegetable frying oils for water-related impacts.

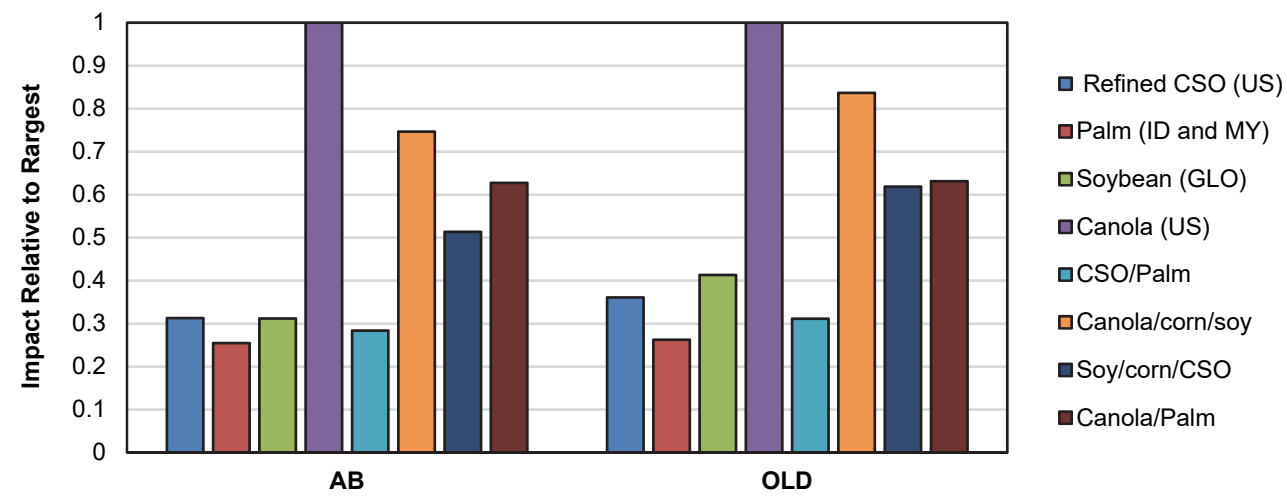

Figure 5. Comparative analysis of vegetable frying oils for resource-related impacts.

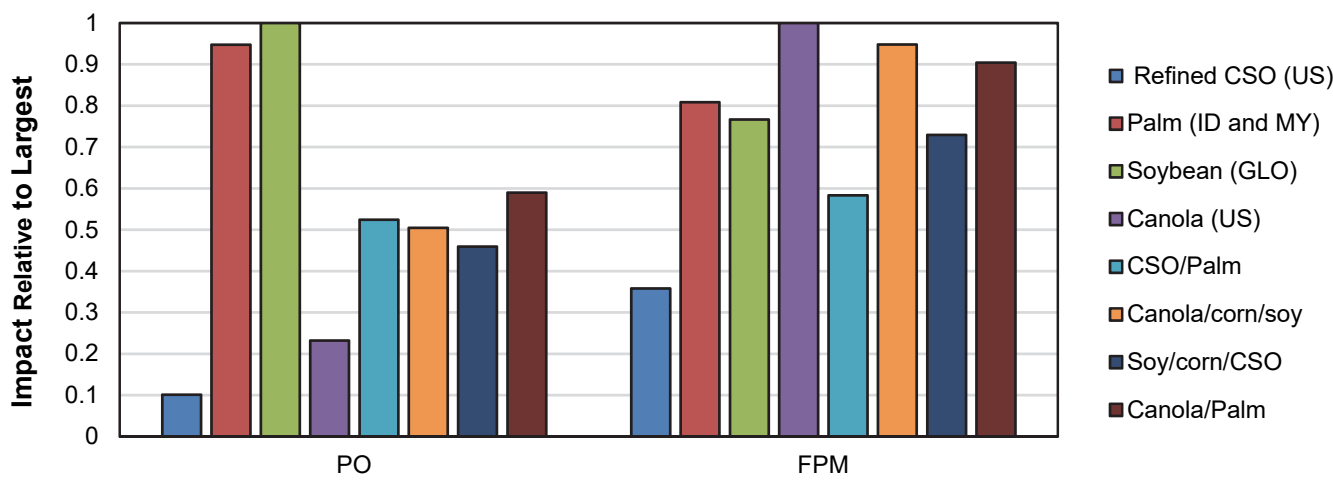

Figure 6. Comparative analysis of vegetable frying oils for air-related impacts.

Figure 5 shows the comparative results for resource-related impacts, including abiotic depletion and ozone layer depletion. Both impact categories show similar trends. Canola oil had the largest impact, while refined CSO (U.S.), palm (ID and MY), and soybean (GLO) had less than $40 \%$ of the impact of canola. These impacts are due to the use of fossil fuels in cultivation and, to a lower extent, in the refining process.

Figure 6 shows the results for the air-related impacts, including photochemical oxidation ( $\mathrm{smog}$ ) and fine particulate matter. The results for these two impact categories show that refined CSO (U.S.) had lower impacts, with larger differences for photochemical oxidation. The high impacts of photochemical oxidation for palm (ID/MY) and soybean (GLO) were due to land use change impacts.

\section{SENSITIVITY TO ECONOMIC VERSUS \\ MASS-BASEd Allocation}

The sensitivity analysis described in this section examines the change in results with respect to changing the allocation approach from the default economic allocation to a mass-based allocation. When applying a mass-based allocation, the impacts of refined CSO (U.S.) increased, mainly due to the cultivation phase in which more seed was produced than cotton lint; therefore, the seed was burdened with a greater share of the cultivation impact. The impact increased by $40 \%$ on average; however, shifting the burden to cottonseed with a mass-based allocation does not reflect the reality that the main driver of cotton cultivation is the lint used for textile applications.

The switch to mass-based allocation for the other vegetable oil systems had an effect mainly on the milling impacts, where 
the overall impacts of the oil portion decreased because more meal was produced than crude oil. Oil refining generates a small portion of co-products on an economic and mass basis; therefore, the partitioning coefficients for these two approaches are at most 1\% apart (table A1 in Appendix A).

A comparison of the impacts with mass-based allocation (fig. 7) shows that refined CSO (U.S.) had the lowest climate change impact, followed closely by soybean (GLO), which had the highest climate change impacts based on an economic allocation (fig. 3). The environmental performance of refined CSO (U.S.) relative to the other oils with mass-based allocation reflects the main trends of lower climate change impact and higher water impact. With a mass-based allocation and cultivation impacts increasing for cottonseed, the impacts of refined CSO (U.S.) also increased for impact categories relative to the other oils. This change illustrates the effect of cultivation allocation in a multifunctional system such as cotton.

The application of mass-based allocation helps us explore the robustness of the baseline results by applying an alternative perspective to the problem of multifunctionality. While the problem of multifunctionality has no absolute answer, an economic allocation is most often used as the baseline case because economic parameters are the driver of economic activity. If the market changes so that the seed becomes the driver in cotton cultivation, then mass-based allocation would become the economic driver.

The application of mass partitioning factors, rather than economic partitioning factors, produces more prominent changes for some oil systems than for others (table D6 in Appendix D). In the refined CSO (U.S.) system, a switch from economic partitioning to mass partitioning produced an overall increase in impact of close to $50 \%$ for water scarcity, eutrophication, and abiotic depletion, all due to increased cultivation impacts with a mass-based allocation. The only reduction was for photochemical oxidation $(3 \%)$, the category in which milling has the highest contribution, where mass-based allocation reduced the impact of the oil portion (more meal is produced than oil in the milling process). Unlike the refined CSO (U.S.) system, the other oils had a decrease in impact, from less than $10 \%$ for palm oil to over $50 \%$ for canola (U.S.) and soybean (GLO). This trend can be explained based on the smaller deviation between the economic and mass partitioning coefficients in the palm oil system as compared to canola and soybean (table A1 in Appendix A).

\section{SENSITIVITY TO ALTERNATIVE ECONOMIC \\ PARTITIONING FACTORS}

The baseline model used economic factors from Ecoinvent (table A1 in Appendix A), but these factors can change over time, depending on market prices. The oil is the most valuable product in milling and refining. The sensitivity analysis (fig. 8) explored a range of economic partitioning factors across the vegetable oil systems based on market prices from 2017 onward (table D7 in Appendix D) to evaluate the robustness of the allocation modeling in this study.

Figure 8 shows that cottonseed oil had the smallest variation, as market prices remained stable, and soybean oil was the most variable. An important measure here is the oil-tomeal ratio, which, not surprisingly, is also the most variable for soybean (table D7 in Appendix D). This sensitivity analysis shows that, when testing alternative economic factors and considering the variability of the results, the conclusions that remain unaltered for refined CSO (U.S.) are its relative performance for climate change, photochemical oxidation, and water scarcity. In all analyses, the refined CSO (U.S.) system had the lowest climate change impact as compared to the other oils examined in this study.

\section{Probabilistic RANKING OF \\ FRYING OILS VIA SMAA}

Based on the comparative results, no single oil was best in all the environmental impact categories. To understand the tradeoffs in environmental impacts, the SMAA method was applied to generate an overall ranking of the oils examined in this study. The results (fig. 9) showed that refined CSO (U.S.) has the highest likelihood (72.3\%) of ranking first, followed by soybean (GLO), palm (ID and MY), and canola (U.S.) in the last place.

Despite the tradeoffs, refined CSO (U.S.) appears to be the best compromise considering its performance across the environmental impact categories. One of the reasons for this conclusion is that the impacts for which refined CSO (U.S.) performed worst were also the impacts with the highest uncertainties, where the differences between oils are less significant. On the other hand, refined CSO (U.S.) performed best for climate change and second best for the impact categories with lower uncertainties, where the differences between oils are more significant (table E1 in Appendix E). This type of ranking ensures that decision-makers consider the areas in which a change will make the most difference.

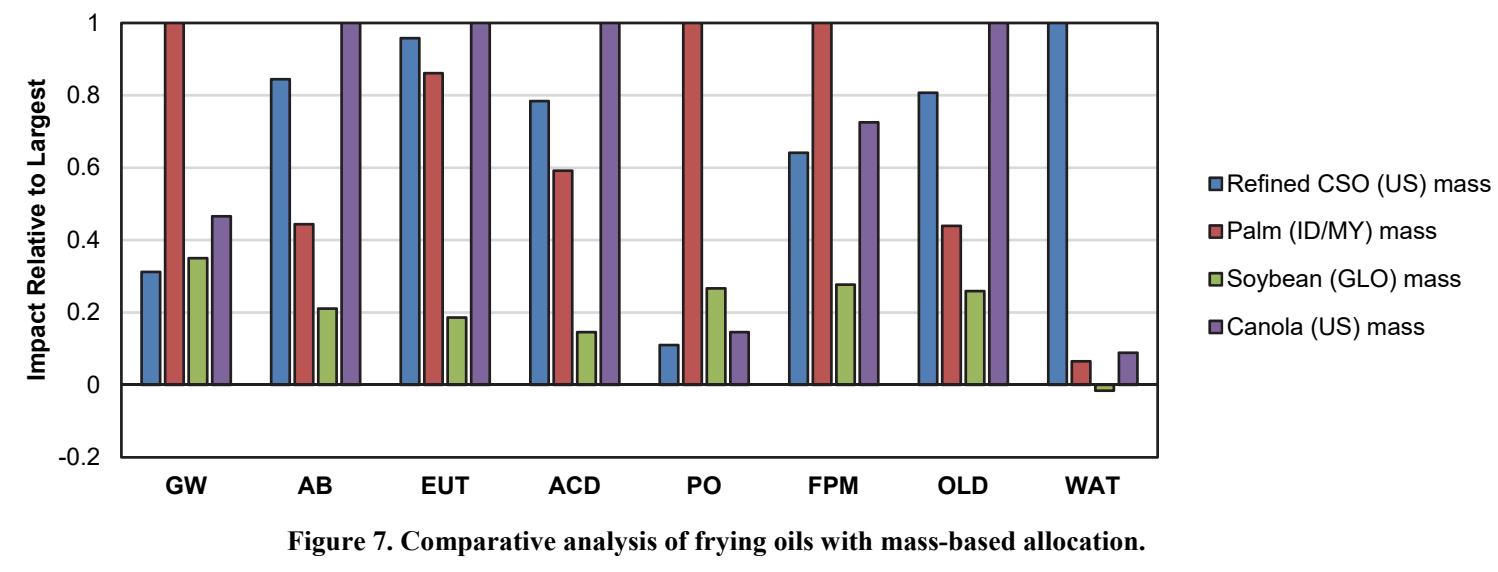




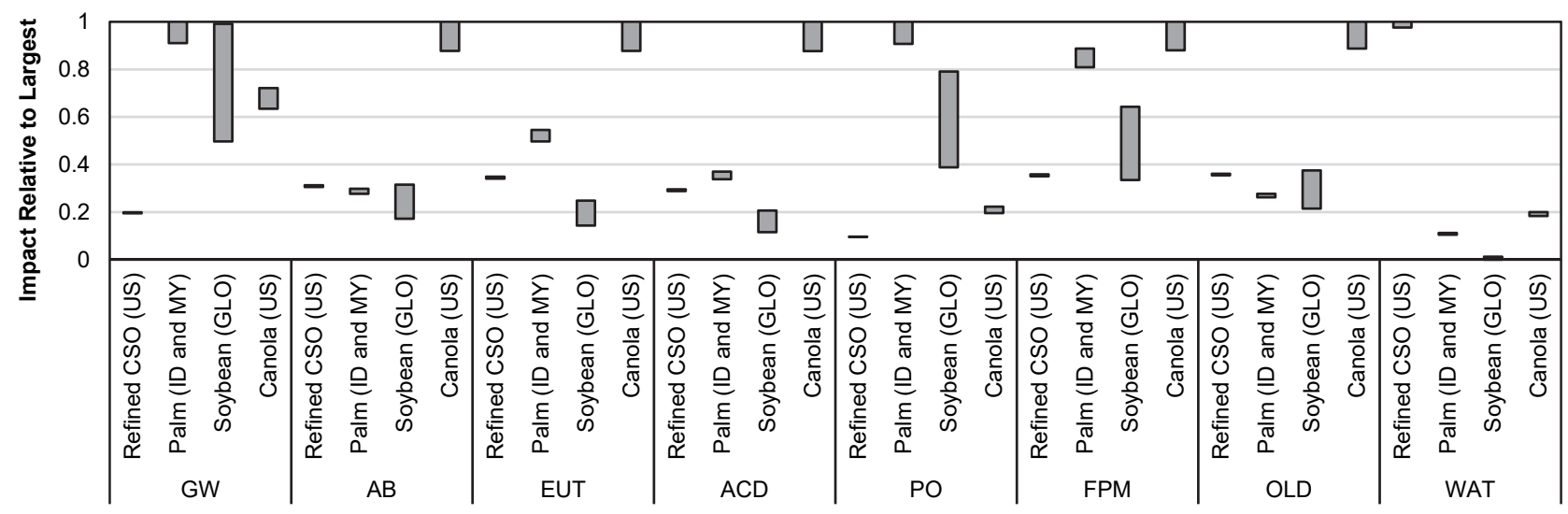

Figure 8. Comparative analysis results considering a range of economic partitioning factors.

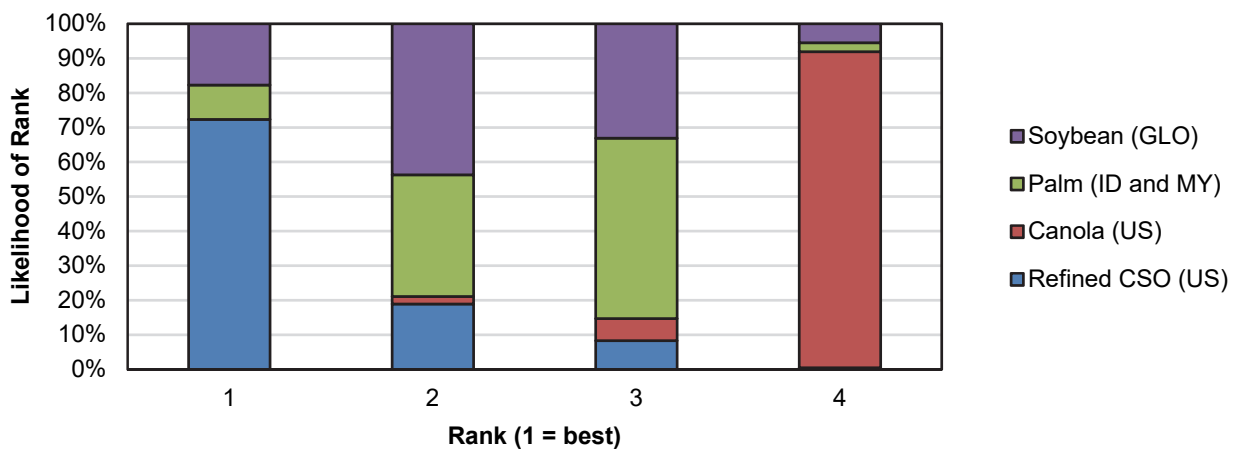

Figure 9. Ranking results with SMAA of $1 \mathrm{~kg}$ of vegetable frying oils.

\section{DisCUSSION}

This study showed that cultivation is the main source of climate change impacts for the vegetable oil systems evaluated, which in turn is one of the environmental advantages of refined CSO (U.S.) because it is derived from a cultivation by-product. Comparative analysis show that refined CSO (U.S.) can reduce climate change impacts by up to $83 \%$ compared to soybean (GLO), and the difference is statistically significant. Further analysis tested key assumptions of the model related to allocation because CSO shares cultivation impacts with cotton lint. When applying mass-based allocation, the impacts of refined CSO (U.S.) increased because of increased cultivation impacts for the seed portion, although the advantage in climate change impact remained as compared to the other oils. When testing a range of economic partitioning factors to account for market variability, the relatively better performance of cotton also remained.

When considering the full extent of the impact categories, there are tradeoffs, and there was no single best oil. Canola oil tended to have higher impacts overall, and refined CSO (U.S.) tended to have lower impacts. In fact, refined CSO (U.S.) performed among the top two oils for six of the eight impact categories. The tradeoff with refined CSO (U.S.) pertains to the water scarcity impact, which relates to growing the crop in an arid region. Nevertheless, when accounting for the uncertainty in all impact categories and ranking the oil alternatives, refined CSO (U.S.) had a $72 \%$ likelihood of ranking first, i.e., with the lowest overall environmental impact. This means that refined CSO (U.S.) can be an advantageous alternative that reduces the carbon footprint while maintaining a balance of the tradeoffs.

For the fast-food industry, this study estimated a potential carbon footprint reduction of 1,130 to 2,188 tons of $\mathrm{CO}_{2}$-eq per day, provided that a fast-food chain such as McDonald's, which sells 9 million $\mathrm{lb}$ (4 million $\mathrm{kg}$ ) of French fries per day, switched to refined CSO (U.S.) for use as the frying oil. This estimate places the results in the context of the global fast-food industry and its frying oil consumption. The potential savings are also applicable to other commercial uses of vegetable oils, such as consumer products.

The conclusions of this study pertain to the scope of the study, and there are limitations to consider. First, there are impact categories related to agriculture that were not included in this LCA, such as the impact on biodiversity from crop cultivation or from land use changes for crop cultivation. These issues are local and depend on the specific practices implemented. While previous studies have evaluated the biodiversity impacts of seed oil crops globally (Chaudhary and Kastner, 2016; Donald, 2004), those impacts were not accounted for directly in this LCA. Another limitation in the LCA water impact evaluation was the consequences of water use and the tradeoffs associated with land use. Unlike the other crops, cotton is drought-tolerant and can grow in regions where other crops would not be viable; therefore, growing cotton in these regions may increase 
water stress while simultaneously leaving less arid regions for other agricultural activities. The significance of this tradeoff is not easily translated into an LCA framework.

Also not included in the LCA are the impacts on product (French fry) quality, which is a function of the characteristics of the oil mix, the par-frying process, the equipment used, and other factors. These factors were outside the scope of this study and are controlled by each fast-food chain. The main point of this study remains the environmental impacts of refined CSO (U.S.) relative to other oils, if deemed viable from a product quality standpoint.

\section{Conclusions}

Vegetable oils derived from agricultural byproducts can have advantages for climate change mitigation, as is the case with cotton lint production and cottonseed oil. Sustainability decisions are complex, especially within agricultural production systems. Organizations that are seeking to lower the environmental burden of their supply chain should consider the full life cycle and the tradeoffs associated with their decisions. While no single oil had a preferred performance across all the environmental impact categories considered in this study, refined CSO (U.S.) was consistently among the top two oils in six of the eight impact categories. When the alternatives were ranked, refined CSO (U.S.) had the highest likelihood of ranking first.

For fast-food chains seeking to reduce their climate change impacts, the use of refined CSO (U.S.) for frying applications can reduce the carbon footprint of a very popular food product (French fries). The potential savings have a wider reach and can be useful for consumer products to reduce the impacts associated with vegetable oil use. Regardless of the application, it is important to consider other impact categories with high opportunity for improvement, such as water use. In fact, one of the key lessons of this study is that most of the impacts of vegetable frying oils are due to the cultivation phase, which reinforces the need for continuous improvement in agriculture.

\section{REFERENCES}

Al-khusaibi, M., Gordon, M. H., Lovegrove, J. A., \& Niranjan, K. (2012). Provenance of the oil in par-fried french fries after finish frying. J. Food Sci., 71(1), E32-E36. https://doi.org/10.1111/j.1750-3841.2011.02460.x

Bai, Y., Zhai, Y., Ji, C., Zhang, T., Chen, W., Shen, X., \& Hong, J. (2021). Environmental sustainability challenges of China's edible vegetable oil industry: From farm to factory. Resour. Conserv. Recycl., 170, 105606. https://doi.org/10.1016/j.resconrec.2021.105606

Beroe. (2019). Palm oil market currently growing at a CAGR of 4.3 percent, says Beroe Inc. (4 Sept. 2019). Raleigh, NC: Beroe. Retrieved from https://www.beroeinc.com/press/palm-oilmarket-currently-growing-cagr/

Boulay, A.-M., Bare, J., Benini, L., Berger, M., Lathuillière, M. J., Manzardo, A., ... Pfister, S. (2018). The WULCA consensus characterization model for water scarcity footprints: Assessing impacts of water consumption based on available water remaining (AWARE). Intl. J. Life Cycle Assess., 23(2), 368-378. https://doi.org/10.1007/s11367-017-1333-8
Canis, L., Linkov, I., \& Seager, T. P. (2010). Application of stochastic multiattribute analysis to assessment of single-walled carbon nanotube synthesis processes. Environ. Sci. Tech., 44(22), 8704-8711. https://doi.org/10.1021/es102117k

Canada. (2019). Market and stats. Winnipeg, MB, Canola Council of Canada. Retrieved from https://www.canolacouncil.org/markets-stats/

Chaudhary, A., \& Kastner, T. (2016). Land use biodiversity impacts embodied in international food trade. Global Environ. Change, 38, 195-204. https://doi.org/10.1016/j.gloenvcha.2016.03.013

Cotton Incorporated. (2018). LCA update of cotton fiber and fabric life cycle inventory. Cary, NC: Cotton Incorporated. Retrieved from https://resource.cottoninc.com/LCA/2016-LCA-FullReport-Update.pdf

Donald, P. F. (2004). Biodiversity impacts of some agricultural commodity production systems. Conserv. Biol., 18(1), 17-38. https://doi.org/10.1111/j.1523-1739.2004.01803.x

EPA. (2020). Greenhouse gas equivalencies calculator. Washington, DC: U.S. Environmental Protection Agency. Retrieved from https://www.epa.gov/energy/greenhouse-gas-equivalenciescalculator.

FAO. (2019). Food prices monitor analysis. Rome, Italy: United Nations FAO. Retrieved from http://www.fao.org/giews/foodprices/

Fassler, J. (2016). Giving up palm oil might actually be bad for the environment. Smithsonian Magazine (March 2016). Retrieved from https://www.smithsonianmag.com/science-nature/givingup-palm-oil-might-actually-be-bad-environment-180958092/

Ferreira Lima, A. M., Torres Andrade, E., Kiperstok, A., Freitas, G., \& Santos, M., 2017. Environmental impacts of the biodiesel production chain of cotton seed in Bahia, Brazil. Clean Tech. Environ. Policy 19, 1523-1534. https://doi.org/10.1007/s10098017-1347-8

Frischknecht, R., Jungbluth, N., Althaus, H.-J., Hischier, R., Doka, G., Dones, R., ... Nemecek, T. (2007). Overview and methodology. Ecoinvent Report No. 1. Dübendorf, Switzerland: Swiss Center for Life Cycle Inventories. Retrieved from https://www.ecoinvent.org/files/200712_frischknecht_jungbluth _overview_methodology_ecoinvent2.pdf

Golden, S. (2019). A whole new way to love McDonald's: Its climate goals. GreenBiz (14 Nov. 2019). Retrieved from https://www.greenbiz.com/article/whole-new-way-lovemcdonalds-its-climate-goals

Heijungs, R., \& Kleijn, R. (2001). Numerical approaches toward life cycle interpretation five examples. Intl. J. Life Cycle Assess., 6(3), article 141. https://doi.org/10.1007/BF02978732

Hughes, K. (2019). Recent developments in the global cotton market: Cotton by-products. Washington, DC: International Cotton Advisory Committee. Retrieved from https://www.wto.org/english/tratop_e/agric_e/item_3 icac_wto_ cotton_by_products_june_2019_final.pdf

Huijbregts, M. A. J. (2017). ReCiPe 2016 v1.1: A harmonized life cycle impact assessment method at midpoint and endpoint level.

Hunsberger, C., German, L., \& Goetz, A. (2017). "Unbundling" the biofuel promise: Querying the ability of liquid biofuels to deliver on socio-economic policy expectations. Energy Policy, 108, 791-805. https://doi.org/10.1016/j.enpol.2017.04.017

Index Mundi. (2020). Soybean oil and meal monthly prices. Index Mundi. Retrieved from https://www.indexmundi.com/

IPCC. (2007). IPCC Fourth Assessment Report (AR4): The physical science basis. Geneva, Switzerland: Intergovernmental Panel on Climate Change: http://www.ipcc.ch/ipccreports/ar4wg1.htm

Jia, F., Peng, S., Green, J., Koh, L., \& Chen, X. (2020). Soybean supply chain management and sustainability: A systematic 
literature review. J. Cleaner Prod., 255, 120254. https://doi.org/10.1016/j.jclepro.2020.120254

Khatri, P., \& Jain, S. (2017). Environmental life cycle assessment of edible oils: A review of current knowledge and future research challenges. J. Cleaner Prod., 152, 63-76. https://doi.org/10.1016/j.jclepro.2017.03.096

List, G. R. (2016). 2 - Oilseed composition and modification for health and nutrition. In T. A. Sanders (Ed.), Functional dietary lipids (pp. 23-46). Sawston, UK: Woodhead Publishing. https://doi.org/10.1016/B978-1-78242-247-1.00002-8

Mendoza Beltran, A., Prado, V., Font Vivanco, D., Henriksson, P. J., Guineee, J. B., \& Heijungs, R. (2018). Quantified uncertainties in comparative life cycle assessment: What can be concluded? Environ. Sci. Tech., 52(4), 2152-2161. https://doi.org/10.1021/acs.est.7b06365

Mielke, T. (2017). World markets for vegetable oils: Status and prospects. Hamburg, Germany: Oil World. https://doi.org/10.1007/978-1-4939-2493-6_989-1

Mouron, P., Willersinn, C., Möbius, S., \& Lansche, J. (2016). Environmental profile of the Swiss supply chain for french fries: Effects of food loss reduction, loss treatments, and process modifications. Sustainability, 8(12), 1214. Retrieved from https://www.mdpi.com/2071-1050/8/12/1214

Mueller, K. (2020). This is the most popular fast-food menu item of all time. Reader's Digest (24 May 2020). Retrieved from https://www.rd.com/article/mcdonalds-french-fries-mostpopular-item/

NRA. (2017). Arby's: Charged up about energy conservation. (22 Aug. 2017). Washington, DC: National Restaurant Association. Retrieved from https://restaurant.org/articles/news/arbyscharged-up-about-energyconservation\#: : :text=The $\% 20$ quickservice $\% 20$ sandwich $\% 20 \mathrm{ch}$ ain $\% 20$ shares,than $\% 201 \% 2$ C000\%20company\%2Downed $\% 20$ r estaurants.

O'Brien, R. (2002). Chapter 7: Cottonseed oil. In F. D. Gunstone (Ed.), Vegetable oils in food technology: Composition, properties, and uses (1st Ed., pp. 203-230). Oxford, UK: Blackwell Publishing.

Panichelli, L., Dauriat, A., \& Gnansounou, E. (2009). Life cycle assessment of soybean-based biodiesel in Argentina for export. Intl. J. Life Cycle Assess., 14(2), 144-159. https://doi.org/10.1007/s11367-008-0050-8

Parikh, A. A., \& Nelson, D. C. (2013). Fat absorption in commercial french fries depending on oil type and coating. Hospitality Rev., 30(2), article 1. Retrieved from https://digitalcommons.fiu.edu/hospitalityreview/vol30/iss2/1

Prado, V., \& Heijungs, R. (2018). Implementation of stochastic multi-attribute analysis (SMAA) in comparative environmental assessments. Environ. Model. Software, 109, 223-231. https://doi.org/10.1016/j.envsoft.2018.08.021

Prado, V., Cinelli, M., Ter Haar, S. F., Ravikumar, D., Heijungs, R., Guinee, J., \& Seager, T. P. (2019). Sensitivity to weighting in life cycle impact assessment (LCIA). Intl. J. Life Cycle Assess., 25(12), 2393-2406. https://doi.org/10.1007/s11367-019-01718-3

Prado, V., Rogers, K., \& Seager, T. P. (2012). Integration of MCDA tools in valuation of comparative life cycle assessment. In M. A. Curran (Ed.), Life cycle assessment handbook: A guide for environmentally sustainable products (pp. 413-431).

Hoboken, NJ: John Wiley \& Sons. https://doi.org/10.1002/9781118528372.ch19

Prado-Lopez, V., Seager, T. P., Chester, M., Laurin, L., Bernardo, M., \& Tylock, S. (2014). Stochastic multi-attribute analysis (SMAA) as an interpretation method for comparative life-cycle assessment (LCA). Intl. J. Life Cycle Assess., 19(2), 405-416. https://doi.org/10.1007/s11367-013-0641-x
Prado-Lopez, V., Wender, B. A., Seager, T. P., Laurin, L., Chester, M., \& Arslan, E. (2016). Tradeoff evaluation improves comparative life cycle assessment: A photovoltaic case study. $J$. Ind. Ecol., 20(4), 710-718. https://doi.org/10.1111/jiec.12292

PRé Sustainability. (2021). Sustainability that makes a difference. Amersfoort, Netherlands: PRé Sustainability. Retrieved from https://pre-sustainability.com/

Quantis. (2018). World apparel and footwear life cycle assessment database. Lausanne, Switzerland: Quantis. Retrieved from https://quantis-intl.com/metrics/databases/waldb-apparelfootwear/

Rajagopalan, N., Venditti, R., Kelley, S., \& Daystar, J. (2016). Multi-attribute uncertainty analysis of the life cycle of lignocellulosic feedstock for biofuel production. Biofuels Bioprod. Biorefining, 11(2), 269-280. https://doi.org/10.1002/bbb.1737

RBI. (2020). Restaurant brands for good. Toronto, ON, Canada: Restaurant Brands International. Retrieved from https://www.rbi.com/sustainability/our-vision/

Research and Markets. (2019). \$20+ Bn frozen finger chips (frozen french fries) market - Global industry trends, share, size, growth, opportunity and forecast 2019-2024. (21 Feb. 2021). Dublin, Ireland: Research and Markets. Retrieved from https://www.globenewswire.com/newsrelease/2019/02/21/1739451/28124/en/20-Bn-Frozen-FingerChips-Frozen-French-Fries-Market-Global-Industry-TrendsShare-Size-Growth-Opportunity-and-Forecast-2019-2024.html

Ritche, H. (2019). Food production is responsible for one-quarter of the world's greenhouse gas emissions. (6 Nov. 2019). Our World in Data. Retrieved from https://ourworldindata.org/foodghg-emissions

Rupp, R. (2015). Are french fries truly French? National Geographic (8 Jan. 2015). Retrieved from https://www.nationalgeographic.com/culture/article/are-frenchfries-truly-french

Schmidt, J. H. (2010). Comparative life cycle assessment of rapeseed oil and palm oil. Intl. J. Life Cycle Assess., 15(2), 183197. https://doi.org/10.1007/s11367-009-0142-0

Schmidt, J. H. (2015). Life cycle assessment of five vegetable oils. J. Cleaner Prod., 87, 130-138. https://doi.org/10.1016/j.jclepro.2014.10.011

Shaker, M. A. (2015). Comparison between traditional deep-fat frying and air-frying for production of healthy fried potato strips. Intl. Food Res., 22, 1557-1563.

Sleeswijk, A. W., van Oers, L. F. C. M., Guinée, J. B., Struijs, J., \& Huijbregts, M. A. J., 2008. Normalisation in product life cycle assessment: An LCA of the global and European economic systems in the year 2000. Sci. Total Environ. 390 (1), 227-240. https://doi.org/10.1016/j.scitotenv.2007.09.040

Weidema, B. P., Bauer, C., Hischier, R., Mutel, C., Nemecek, T., Reinhard, J., ... Wernet, G. (2013). Overview and methodology: Data quality guideline for the Ecoinvent database version 3 . Ecoinvent Report No. 1 (v3). Dübendorf, Switzerland: Swiss Center Life Cycle Inventories. Retrieved from https://www.ecoinvent.org/files/dataqualityguideline_ecoinvent 3_20130506.pdf

Wernet, G., Bauer, C., Steubing, B., Reinhard, J., Moreno-Ruiz, E., \& Weidema, B. (2016). The Ecoinvent database version 3 (part I): Overview and methodology. Intl. J. Life Cycle Assess., 21(9), 1218-1230. https://doi.org/10.1007/s11367-016-1087-8

Win, T. L. (2019). Investors call on McDonald's and KFC to step up climate change action. Reuters (29 Jan. 2019). Retrieved from https://www.reuters.com/article/us-global-foodclimate/investors-call-on-mcdonalds-and-kfc-to-step-up-climatechange-action-idUSKCN1PN2MD 
Appendix A

Life CyCle ASSESSMENT TABles

Table A1. Mass-based and economic partitioning factors for vegetable oils.

\begin{tabular}{|c|c|c|c|c|}
\hline Phase & $\begin{array}{l}\text { Mass-Based } \\
\text { Partitioning } \\
\text { Coefficient }\end{array}$ & $\begin{array}{l}\text { Economic } \\
\text { Partitioning } \\
\text { Coefficient }\end{array}$ & $\begin{array}{l}\text { Co-product } \\
\text { (remainder of } \\
\text { the impact }\end{array}$ & Assumptions \\
\hline \multicolumn{5}{|l|}{ Refined CSO (U.S.) } \\
\hline $\begin{array}{l}\text { Cultivation } \\
\text { (cottonseed) }\end{array}$ & 0.58 & 0.16 & Fiber & $\begin{array}{l}\text { Seed to fiber mass ratio }=1.4, \text { seed }=\$ 0.11 \mathrm{lb}^{-1}, \text { and fiber }=\$ 0.8 \mathrm{lb}^{-1} \\
\text { (Cotton Incorporated, 2018). }\end{array}$ \\
\hline $\begin{array}{c}\text { Milling } \\
\text { (crude CSO) }\end{array}$ & 0.25 & 0.58 & Meal & $\begin{array}{l}\text { Meal to crude oil mass ratio }=3, \text { crude oil }=\$ 1.04 \mathrm{~kg}^{-1}, \text { meal }=\$ 0.25 \mathrm{~kg}^{-1}, \\
\text { and seed conversion ratio }=5(5 \mathrm{~kg} \text { of seed are converted to } 1 \mathrm{~kg} \text { of crude). }\end{array}$ \\
\hline $\begin{array}{c}\text { Refining } \\
\text { (refined CSO) }\end{array}$ & 0.99 & 0.98 & Soap stock & $\begin{array}{c}\text { Per } 1 \mathrm{~kg} \text { of refined oil produced, } 0.0074 \mathrm{~kg} \text { of soap stock is produced. } \\
\text { Ecoinvent reports prices of } 0.755 \mathrm{EUR}_{2005} \mathrm{~kg}^{-1} \text { for refined oil, } \\
\text { and } 1.73 \mathrm{EUR}_{2005} \mathrm{~kg}^{-1} \text { for soap stock. }\end{array}$ \\
\hline \multicolumn{5}{|l|}{ Palm (ID/MY) } \\
\hline $\begin{array}{l}\text { Cultivation } \\
\text { (palm fruit) }\end{array}$ & 1 & 1 & No co-products & $4.63 \mathrm{~kg}$ of palm fruit bunch are converted to $1 \mathrm{~kg}$ of crude palm oil. \\
\hline $\begin{array}{l}\text { Milling } \\
\text { (crude } \\
\text { palm oil) }\end{array}$ & 0.78 & 0.85 & $\begin{array}{l}\text { Palm kernel } \\
\text { oil and meal }\end{array}$ & $\begin{array}{c}\text { Economic partitioning coefficients provided by Ecoinvent based on prices } \\
\text { of } 0.362 \mathrm{EUR}_{2005} \mathrm{~kg}^{-1} \text { for crude palm oil, } 0.061 \mathrm{EUR}_{2005} \mathrm{~kg}^{-1} \text { for palm kernel } \\
\text { meal, and } 0.444 \mathrm{EUR}_{2005} \mathrm{~kg}^{-1} \text { for palm kernel oil. Mass partitioning } \\
\text { derived from production of } 1 \mathrm{~kg} \text { of crude oil, } 0.15 \mathrm{~kg} \text { of palm } \\
\text { kernel meal, and } 0.12 \text { of palm kernel oil. }\end{array}$ \\
\hline $\begin{array}{l}\text { Refining } \\
\text { (refined } \\
\text { palm oil) }\end{array}$ & 0.99 & 0.97 & Soap stock & $\begin{array}{c}\text { Ecoinvent reports prices of } 0.372 \mathrm{EUR}_{2005} \mathrm{~kg}^{-1} \text { for refined palm oil and } \\
1.73 \mathrm{EUR}_{2005} \mathrm{~kg}^{-1} \text { for soap stock. Per } 1 \mathrm{~kg} \text { of refined palm oil, } \\
0.0074 \mathrm{~kg} \text { of soap stock is produced. }\end{array}$ \\
\hline \multicolumn{5}{|l|}{ Soybean (GLO) } \\
\hline $\begin{array}{l}\text { Cultivation } \\
\text { (soybean) }\end{array}$ & 1 & 1 & No co-products & $5.35 \mathrm{~kg}$ of soybeans are converted to $1 \mathrm{~kg}$ of crude soybean oil. \\
\hline $\begin{array}{l}\text { Milling } \\
\text { (crude } \\
\text { soybean oil) }\end{array}$ & 0.19 & 0.70 & Soybean meal & $\begin{array}{c}\text { Mass partitioning derived from production reported by Ecoinvent: } 1.27 \mathrm{~kg} \\
\text { of soybean produced } 1 \mathrm{~kg} \text { of meal and } 0.237 \mathrm{~kg} \text { of crude oil. Prices are } \\
0.1236 \mathrm{EUR}_{2005} \mathrm{~kg}^{-1} \text { for meal and } 1.2215 \mathrm{EUR}_{2005} \mathrm{~kg}^{-1} \text { for crude oil. }\end{array}$ \\
\hline $\begin{array}{l}\text { Refining } \\
\text { (refined } \\
\text { soybean oil) }\end{array}$ & 0.99 & 0.99 & Soap stock & $\begin{array}{l}\text { Ecoinvent reports prices of } 1.7101 \mathrm{EUR}_{2005} \mathrm{~kg}^{-1} \text { for refined soybean oil and } \\
1.73 \mathrm{EUR}_{2005} \mathrm{~kg}^{-1} \text { for soap stock. Per } 1 \mathrm{~kg} \text { of refined soybean oil, } 0.0074 \mathrm{~kg} \\
\text { of soap stock is produced. }\end{array}$ \\
\hline \multicolumn{5}{|l|}{ Canola (U.S.) } \\
\hline $\begin{array}{l}\text { Cultivation } \\
\text { (rapeseed) }\end{array}$ & 1 & 1 & No co-products & $2.6 \mathrm{~kg}$ of rapeseed are converted to $1 \mathrm{~kg}$ of crude canola oil. \\
\hline $\begin{array}{l}\text { Milling } \\
\text { (crude } \\
\text { canola oil) }\end{array}$ & 0.38 & 0.72 & Rapeseed meal & $\begin{array}{l}\text { Mass partitioning factors derived from production reported by Ecoinvent: } \\
2.6 \mathrm{~kg} \text { of rapeseed produced } 1.6 \mathrm{~kg} \text { of rapeseed meal and } 1 \mathrm{~kg} \text { of crude } \\
\text { canola oil. Prices are } 0.127 \mathrm{EUR}_{2005} \mathrm{~kg}^{-1} \text { for rapeseed meal } \\
\text { and } 0.538 \mathrm{EUR}_{2005} \mathrm{~kg}^{-1} \text { for crude canola oil. }\end{array}$ \\
\hline $\begin{array}{l}\text { Refining } \\
\text { (refined } \\
\text { canola oil) } \\
\end{array}$ & 0.99 & 0.98 & Soap stock & $\begin{array}{l}\text { CSO refining used as a proxy: } 0.0074 \mathrm{~kg} \text { of soap stock is produced } \\
\text { per } 1 \mathrm{~kg} \text { of refined canola oil produced. Ecoinvent reported prices of } \\
0.755 \mathrm{EUR}_{2005} \mathrm{~kg}^{-1} \text { for refined oil and } 1.73 \mathrm{EUR}_{2005} \mathrm{~kg}^{-1} \text { for soap stock. }\end{array}$ \\
\hline
\end{tabular}


Table A2. Description of inventory for refined oils in each phase.

\begin{tabular}{|c|c|c|c|}
\hline $\begin{array}{l}\text { Oil and } \\
\text { Source }\end{array}$ & Cultivation & Milling & Refining \\
\hline $\begin{array}{l}\text { CSO } \\
\text { (U.S.) }\end{array}$ & $\begin{array}{l}\text { U.S. cottonseed cultivation is sourced from } \\
\text { the WALDB LCA project, which updated } \\
\text { cotton cultivation impacts in } 2018 \text {. A global } \\
\text { dataset is undergoing review to be included } \\
\text { in Ecoinvent. However, this project uses the } \\
\text { U.S. average component. System data were } \\
\text { provided by Quantis from these critically re- } \\
\text { viewed data. The process applies economic } \\
\text { allocation for cultivation, milling, and refin- } \\
\text { ing as described in this article. This cotton- } \\
\text { seed dataset replaces Ecoinvent's global in- } \\
\text { ventory of "Cotton seed \{GLO\}| market for } \\
\text { |Cut-off, U" with a U.S. context. }\end{array}$ & $\begin{array}{l}\text { Uses solvent extraction. Partly based on } \\
\text { rapeseed oil milling as modeled by Ecoin- } \\
\text { vent. The Ecoinvent process of "Cottonseed } \\
\text { oil, crude }\{\mathrm{GLO}\} \mid \text { market for | Cut-off, U" } \\
\text { is modified by changing electricity to the } \\
\text { U.S. average and changing the cottonseed } \\
\text { input to the most recent dataset obtained } \\
\text { from WALDB. }\end{array}$ & $\begin{array}{l}\text { Average technology for alkaline refining in } \\
\text { which caustic soda is added to degummed } \\
\text { crude oil, which reacts with free fatty acids } \\
\text { to form soap stock. The oil/soap mixture is } \\
\text { separated using a centrifuge, and filtration is } \\
\text { performed to further clarify the oil from the } \\
\text { soap. Modeling uses "Cottonseed oil, re- } \\
\text { fined }\{\text { U.S.\}| cottonseed oil refinery opera- } \\
\text { tion } \mid \text { Cut-off, U" and modifies crude oil in- } \\
\text { put. The process is based on soybean oil re- } \\
\text { fining and uses U.S. electricity, i.e., "Elec- } \\
\text { tricity, medium voltage \{U.S.\}| market } \\
\text { group for } \mid \text { Cut-off, U". }\end{array}$ \\
\hline $\begin{array}{c}\text { Palm } \\
\text { (ID/MY) }\end{array}$ & $\begin{array}{l}\text { Cultivation of palm fruit assumes a mix of } \\
67 \% \text { Indonesian palm and } 33 \% \text { Malaysian } \\
\text { palm, following their relative contributions } \\
\text { to the global market. Together, their produc- } \\
\text { tion }>90 \% \text { of the global market. Cultivation } \\
\text { data for each source of palm fruit are } \\
\text { sourced from two Ecoinvent processes: } \\
\text { "Palm fruit bunch }\{\text { MY }\} \mid \text { production } \mid \text { Cut- } \\
\text { off, U" and "Palm fruit bunch }\{\text { ID }\} \mid \text { palm } \\
\text { fruit bunch production } \mid \text { Cut-off, U". }\end{array}$ & $\begin{array}{l}\text { Process includes extraction of crude palm } \\
\text { oil, palm kernel oil, and meal from fruit } \\
\text { bunches, taking into account energy recov- } \\
\text { ery and effluent treatment. The default pro- } \\
\text { cess applies economic allocation in which } \\
81.3 \% \text { of impacts are assigned to crude } \\
\text { palm oil. The remaining impacts are allo- } \\
\text { cated to palm kernel oil (17.3\%) and meal } \\
(1.4 \%) \text { The Ecoinvent process "Palm oil, } \\
\text { crude \{RoW\}| palm oil mill operation | Cut- } \\
\text { off, U" is modified for a mix of fruit } \\
\text { bunches from Indonesia and Malaysia. Heat } \\
\text { is used during the conversion process. } 4.63 \\
\mathrm{~kg} \text { of fruit bunch yields } 1 \mathrm{~kg} \text { of crude oil. }\end{array}$ & $\begin{array}{l}\text { Refining of crude palm oil is based on soy- } \\
\text { bean oil refining and modeled in Ecoinvent } \\
\text { in "Palm oil, refined \{GLO\}| palm oil refin- } \\
\text { ery operation | Cut-off, U". This process is } \\
\text { modified to include crude palm oil with the } \\
\text { selected fruit mix. Data consist of average } \\
\text { technology for alkaline refining in which } \\
\text { caustic soda is added to degummed crude } \\
\text { oil, which reacts with free fatty acids to } \\
\text { form soap stock. The oil/soap mixture is } \\
\text { separated using a centrifuge and filtration. } \\
\text { Less than } 1 \% \text { is lost when transforming } \\
\text { crude palm oil into refined oil. }\end{array}$ \\
\hline $\begin{array}{c}\text { Soybean } \\
(\text { GLO) }\end{array}$ & $\begin{array}{l}\text { Market mix of soybeans depending on the } \\
\text { crude soybean oil mix. Soybean processes } \\
\text { used correspond to U.S., Switzerland, Bra- } \\
\text { zil, Argentina, Canada, and a global aver- } \\
\text { age. Activities include agricultural opera- } \\
\text { tions to sow, till, fertilize, apply pesticides, } \\
\text { and harvest. }\end{array}$ & $\begin{array}{l}\text { Study uses a global crude soybean oil mix } \\
\text { ("Soybean oil, crude }\{\text { GLO }\} \mid \text { market for } \mid \\
\text { Cut-off, U"). The process includes a market } \\
\text { mix of } 54 \% \text { global average soybean crude, } \\
16 \% \text { U.S. soybean crude, } 14 \% \text { Brazilian } \\
\text { soybean crude, and the remaining portion is } \\
\text { supplied by milling in Europe, Canada, and } \\
\text { a global mix of mechanical extraction. The } \\
\text { difference between regions is the electricity } \\
\text { mix and soybean source. Soybean crude } \\
\text { production includes conversion of soybean } \\
\text { to crude oil and meal. Technology consists } \\
\text { of solvent extraction, which includes pre- } \\
\text { cracking of soybeans, dehulling, oil extrac- } \\
\text { tion, meal processing, and oil purification. } \\
\text { Impacts between crude and meal are allo- } \\
\text { cated on an economic basis. } 5.35 \text { kg of soy- } \\
\text { beans are converted to } 1 \mathrm{~kg} \text { of crude oil. }\end{array}$ & $\begin{array}{l}\text { Production of refined soybean oil (and soap } \\
\text { stock) from crude soybean oil. Global pro- } \\
\text { cess from Ecoinvent ("Soybean oil, refined } \\
\{\text { GLO }\} \mid \text { market for | Cut-off, U") models a } \\
\text { market mix of refining in which } 78 \% \text { uses a } \\
\text { global energy mix and } 22 \% \text { uses the average } \\
\text { U.S. grid. The underlying soybean crude oil } \\
\text { is the same and corresponds to a global mix. } \\
\text { Refining technology is the same as for palm } \\
\text { oil and cottonseed oil. Impacts are allocated } \\
\text { on an economic basis. } 1.034 \mathrm{~kg} \text { of soybean } \\
\text { crude oil is converted to } 1 \mathrm{~kg} \text { of refined oil } \\
\text { for both the global and U.S. underlying re- } \\
\text { fining processes. }\end{array}$ \\
\hline $\begin{array}{l}\text { Canola } \\
\text { (U.S.) }\end{array}$ & $\begin{array}{l}\text { Dataset represents } 1 \mathrm{~kg} \text { of U.S. rapeseed } \\
\text { production (fresh matter): "Rapeseed } \\
\text { \{U.S.\}| production | Cut-off, U". The da- } \\
\text { taset includes infrastructure and activities } \\
\text { for soil cultivation, sowing, fertilization, } \\
\text { weed control, pest and pathogen control, } \\
\text { combine harvest, transport from field to } \\
\text { farm }(1 \mathrm{~km}) \text {, and drying of grain. Direct } \\
\text { field emissions are included. }\end{array}$ & $\begin{array}{l}\text { Based on an Ecoinvent dataset for the rape- } \\
\text { seed crude oil market ("Rape oil, crude } \\
\text { \{RoW\}| rape oil mill operation | Cut-off, } \\
\text { U") with a modified mix of incoming rape- } \\
\text { seed so that all rapeseed comes from the } \\
\text { U.S. Processes include transport of rapeseed } \\
\text { to the mill and processing of seed to crude } \\
\text { oil and meal by solvent extraction with pre- } \\
\text { pressing of rapeseed. Impacts are assigned } \\
\text { on an economic basis in which crude oil } \\
\text { represents } 75 \% \text { of impacts. } 1 \mathrm{~kg} \text { of rapeseed } \\
\text { is converted to } 0.38 \mathrm{~kg} \text { of crude canola oil. }\end{array}$ & $\begin{array}{l}\text { Refining of crude canola oil is based on soy- } \\
\text { bean oil refining with U.S. electricity, the } \\
\text { same as with refining of crude cottonseed } \\
\text { oil. } 1.025 \mathrm{~kg} \text { of crude oil is converted to } 1 \\
\mathrm{~kg} \text { of refined oil. }\end{array}$ \\
\hline $\begin{array}{l}\text { Corn } \\
\text { (U.S.) }\end{array}$ & $\begin{array}{l}\text { Dataset presents production mix of maize in } \\
\text { the U.S. based on production quantities per } \\
\text { state. The dataset is originally modeled in } \\
\text { agri-footprint data by "Crude maize germ } \\
\text { oil, from wet milling (germ oil production, } \\
\text { pressing), at plant/U.S. Economic". This } \\
\text { study replicates the process using equivalent } \\
\text { components in the Ecoinvent library for } \\
\text { consistency with the other oil systems. }\end{array}$ & $\begin{array}{l}\text { Wet milling process consisting of mechani- } \\
\text { cal pressing steps. Dataset produces crude } \\
\text { corn oil and corn meal to be allocated on an } \\
\text { economic basis. Here, crude oil represents } \\
82 \% \text { of impacts. } 3.03 \mathrm{~kg} \text { of dried maize } \\
\text { germ are converted to } 1 \mathrm{~kg} \text { of crude oil. }\end{array}$ & $\begin{array}{l}\text { The study assumes that the corn oil used in } \\
\text { oil mixes is not refined. }\end{array}$ \\
\hline
\end{tabular}




\section{APPENDIX B}

The secondary functional unit in this study concerned the amount of frying oil required for $1 \mathrm{~kg}$ of French fries at a fast-food restaurant, which corresponded to $0.1 \mathrm{~kg}$ of frying oil. Given the linearity of LCA models, the impact would be $1 / 10$ of the first functional unit, but the secondary functional unit helps place the results in the context of one of the main applications of frying oil. For this application, it is assumed that the amount of oil required is the same across vegetable oil systems because, in a commercial application, the oil is absorbed faster than it can degrade and potential differences among the oils can be ignored in the frying phase.

\section{FrYING MODEL}

The amount of oil needed in an application depends on the amount of food being fried, the fryer capacity, and the oil absorption. The frying model parameters are shown in table B1. The fryer performance is based on a high-capacity commercial fryer (AutoFry MTI-40E), which is designed to fry up to $54 \mathrm{~kg}$ of food product per hour.

The oil is continuously absorbed by the food as a function of the food mass. In each hourly interval, this absorbed oil is replenished with new oil. In the first few hours, the oil consumption rate is high due to the oil required to fill the fryer; however, as time go by, the oil consumption rate drops exponentially and reaches equilibrium at $0.1 \mathrm{~kg}^{\mathrm{oil} \mathrm{kg}} \mathrm{kg}^{-1}$ fried food after approximately $24 \mathrm{~h}$ of continuous operation (fig. B1). This calculation assumes that the fryer is operating non-stop at full capacity, which is the case in most fast-food restaurants. This frying oil consumption per $\mathrm{kg}$ of food agrees with the literature, i.e., between $10 \%$ and $15 \%$ (Shaker, 2015; Parikh and Nelson, 2013).

This estimated oil consumption corresponds to final frying at a restaurant. French fries are usually par-fried, but most of the oil in the food product (about 90\%) corresponds to the final frying (Al-khusaibi et al., 2012). Therefore, this amount of frying oil, i.e., $10 \%$ of the mass of French fries at

Table B1. Frying model parameters.

\begin{tabular}{|c|c|c|}
\hline Parameter & Value & Source \\
\hline Fryer energy & $12 \mathrm{~kW}$ & \multirow{3}{*}{$\begin{array}{l}\text { MTI-40E data sheet } \\
\text { (mtiproducts.com) }\end{array}$} \\
\hline Oil capacity & $23 \mathrm{~L}$ & \\
\hline Food output & $\begin{array}{l}54 \mathrm{~kg} \mathrm{~h}^{-1} \\
\text { maximum }\end{array}$ & \\
\hline Daily use & $24 \mathrm{~h} \mathrm{~d}^{-1}$ & $\begin{array}{c}\text { Assumption based on hours of } \\
\text { operation of fast-food restaurants }\end{array}$ \\
\hline Oil absorption & $9.7 \%$ & $\begin{array}{l}\text { Average amount absorbed by French } \\
\text { fries taking into account different oil } \\
\text { types (Parikh and Nelson, 2013). }\end{array}$ \\
\hline
\end{tabular}

Table B2. Reference flow for the oil required for $1 \mathrm{~kg}$ of French fries at the restaurant gate.

\begin{tabular}{cc}
\hline $\begin{array}{c}\text { Reference Flow for 1 kg of } \\
\text { French Fries at Restaurant Gate }\end{array}$ & $\begin{array}{c}\text { Oil Consumed } \\
\left(\mathrm{kg} \mathrm{oil} \mathrm{kg}^{-1} \text { fried food }\right)\end{array}$ \\
\hline All oil types compared in this study & 0.10 \\
\hline
\end{tabular}

a fast-food restaurant, is an illustration of the oil consumption. The specific oil consumption depends on the specific circumstances. For the purposes of this study, the oil consumption is the same for the different frying oils.

In high-volume frying, the oil is absorbed by the food faster than it can be degraded. Therefore, differences in stability among the different oil types are not accounted for in the simulation of oil consumption (fig. B1). Our model calculates that the original oil is fully absorbed after $5 \mathrm{~h}$ and assumes that the oil absorbed corresponds to the mix of oil in the fryer. Therefore, this study considers a case in which the amount of oil required is the same regardless of the oil type and avoids considering the degradation rates of different oils. The reference flow is shown in table B2. The value of $0.1 \mathrm{~kg}$ oil kg-1 fried food corresponds to the $9.7 \%$ oil absorption value in table $\mathrm{B} 1$.

At the end of the oil's useful life, it is assumed that any oil not absorbed by French fries is used in the production of biodiesel. As discussed below, the use of a cutoff allocation between frying oil and biodiesel allocates all the burdens of used frying oil collection and processing to the biodiesel. These assumptions apply equally to all the frying oil types.

\section{IMPACTS OF $1 \mathrm{~kg}$ OF FRENCH FRIES \\ AT RESTAURANT GATE}

The frying model estimates $0.1 \mathrm{~kg}$ oil kg-1 French fries. The assumptions in the analysis used the same mass of oil, the same replacement rate, the same temperature profile, and the same yield of French fries across all vegetable frying oil systems. This analysis concerns only the oil portion to estimate the impact of the choice of oil for cooking French fries. Because LCA is linear, the results of this application are, not surprisingly, 1/10 of the baseline results. However, provided that fast-food chains have set carbon reduction targets, it is possible to relate the results of this study to their climate goals.

Specifically, if a fast-food chain switched to refined CSO (U.S.) for frying, the climate change impacts could be reduced by $83 \%$ for switching from soybean (GLO), by $78 \%$ for switching from palm (ID and MY), and by $72 \%$ for switching from canola (U.S.). This leads to an absolute reduction of 0.27 to $0.53 \mathrm{~kg} \mathrm{CO} \mathrm{kg}^{-1}$ French fries when considering a change from another single-source oil (not mixes)

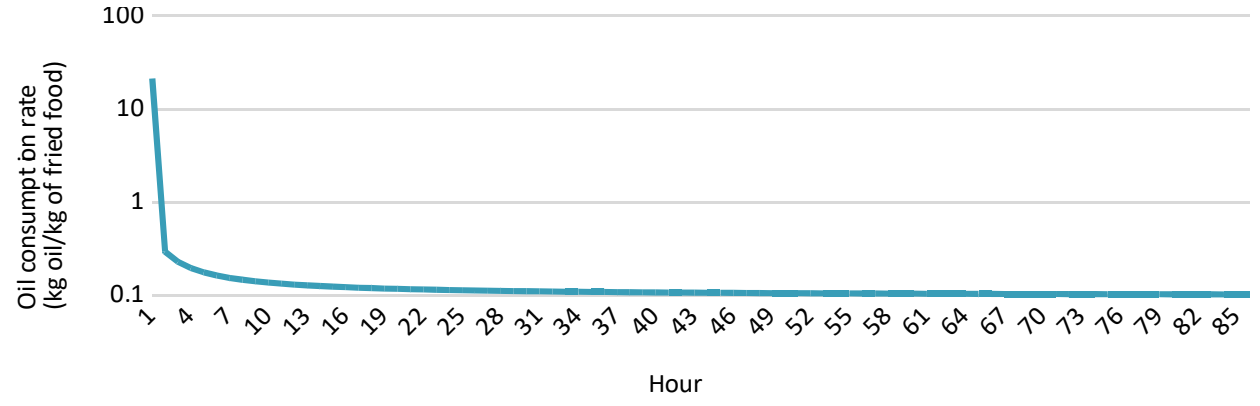

Figure B1. Frying oil consumption rate. 


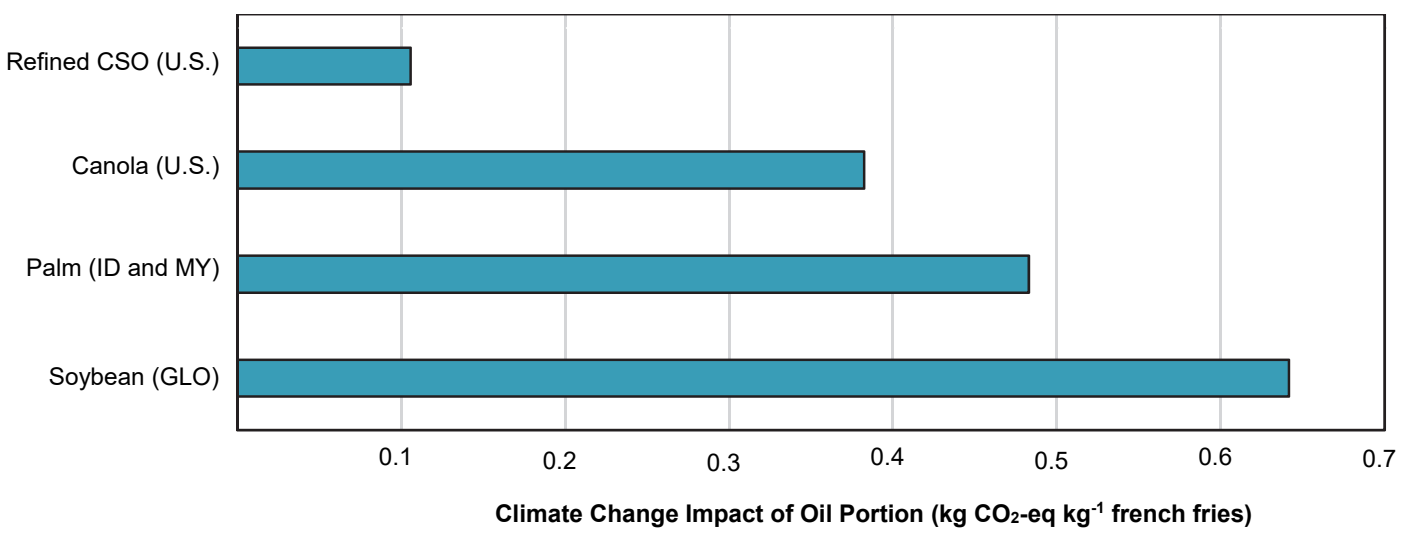

Figure B2. Climate change impacts of $0.1 \mathrm{~kg}$ of vegetable oil required to cook $1 \mathrm{~kg}$ of French fries in a commercial fryer.

to refined CSO (U.S.). This reduction may not seem large on a per kilogram basis; however, when extrapolated to the estimated 9 million $\mathrm{lb}(4$ million $\mathrm{kg}$ ) of French fries that McDonald's sells every day, the reduction is 1,130 to 2,188 tons of $\mathrm{CO}_{2}$ per day. This reduction is equivalent to the annual energy consumption of 130 to 252 U.S. homes.

This analysis showed that the climate impacts due to frying oil are less for refined CSO (U.S.) than for the other oils (fig. B2) and provides a pathway for climate impact reductions. For example, replacing soybean (GLO) with refined CSO (U.S.) can reduce climate change impacts by almost $50 \%$. Although these results may underestimate the climate change impacts of producing French fries, they are useful as a guide for fast-food chains' carbon reduction efforts.

The only difference in this analysis was the type of oil used. We assumed an identical oil mass, replacement rate, temperature profile, yield of French fries, and electricity demand for the fryer. The impacts measured in each case were those specific to $0.1 \mathrm{~kg}$ oil kg-1 French fries. When considering the consumer scale and the estimated $29 \mathrm{lb}(13 \mathrm{~kg})$ of French fries that the average American consumes each year (Rupp, 2015), a switch in the oil can lead to a savings of 3.6 to $7.0 \mathrm{~kg} \mathrm{CO}_{2}$ year-1 per average American consumer. This information can also support fast-food chains' carbon reduction targets.

\section{Appendix C}

In comparative analyses, it is important to describe the data quality used for each system and thereby identify limitations of the conclusions (ISO 14044, Section 4.2.3.6.2). The elements to be discussed include the temporal coverage, geographic coverage, technology coverage, precision, completeness, representativeness, consistency, reproducibility, data sources, and uncertainty. This section includes a description of these data quality elements for vegetable frying oil systems.

\section{DATA QUALITY FOR REFINED CSO (U.S.)}

Temporal coverage: The temporal coverage for cultivation is 2015 to 2018 (as described in the cottonseed unit process available in Ecoinvent version 3.6). Milling and refining of cottonseed have a temporal coverage of 2012 to 2017.
Geographic coverage: Cultivation of cottonseed pertains to U.S. average data. Milling and refining are modeled on global averages.

Technology coverage: Cultivation includes an average of technologies used in the U.S. considering a variation of agrochemicals, irrigation, and yields. The technology for milling and refining is based on soybean systems.

Precision and completeness: This dataset can be considered quite complete, with emissions reported for every unit process. This aspect is further addressed in the uncertainty analysis.

Representativeness: The system is representative of the intended geography and technology, as it is the latest dataset for average U.S. cotton cultivation. Because milling and refining are not specific to cottonseed oil extraction, this would be a source of uncertainty. However, milling and refining are general processes, with the main variation being the oil content of the seed, which is taken into consideration. This aspect is further addressed in the uncertainty analysis.

Consistency and reproducibility: The data gathered all follow the same approach as performed by Ecoinvent; therefore, the same datasets can be accessed by other LCA practitioners, making the results reproducible. Any changes to the original datasets are documented in this study.

Data sources: For cottonseed oil, the data for cottonseed milling and refining come from Ecoinvent, and the cultivation data are sourced from the World Apparel and Footwear Lifecycle Assessment Database (WALDB) for U.S. cotton cultivation (Quantis, 2018). Any extrapolations done in the original dataset are reflected in the data quality coefficients used in uncertainty estimation.

\section{Data Quality for Palm (ID AND MY)}

Temporal coverage: Starting from the cultivation of Indonesian and Malaysian palm fruit bunches, the temporal coverages are 2009 to 2018 and 2002 to 2018 , respectively. Milling of palm fruit from both sources has a temporal coverage of 1995 to 2006 with extrapolation to 2017. Refining of oil has a temporal coverage of 2012 to 2017. 
Geographic coverage: The geography of palm fruit cultivation corresponds to average Indonesian and Malaysian cultivation. Milling is based on palm oil mills in Malaysia, and refining is based on global averages.

Technology coverage: Cultivation includes an average of technologies used in the corresponding countries of origin. Milling data in Ecoinvent are based on Malaysian oil mills, and refining is based on soybean systems.

Precision and completeness: The dataset can be considered complete, with emissions reported for every unit process. This aspect is further addressed in the uncertainty analysis.

Representativeness: The system is representative of the intended geography and technology up to milling. Because refining is not specific to palm oil, this would be a source of uncertainty. However, refining is a general process, with the main variation being the oil content of the seed, which is taken into consideration. This aspect is further addressed in the uncertainty analysis.

Consistency and reproducibility: The data gathered all follow the same approach as performed by Ecoinvent; therefore, the same datasets can be accessed by other LCA practitioners, making the results reproducible. Any changes to the original datasets are documented in this study.

Data sources: All datasets for this system were gathered from Ecoinvent. However, the underlying data were derived from on-site data collection and literature sources. Any extrapolations done in the original dataset are reflected in the data quality coefficients used in uncertainty estimation.

\section{DATA QUALITY FOR SOYBEAN (GLO)}

Temporal coverage: The temporal coverage for cultivation is 2011 to 2018. Milling has a temporal coverage of 1998 to 2005 , and refining has a temporal coverage of 2011 to 2018.

Geographical coverage: Cultivation of soybeans includes a global mix. Milling is based on a U.S. context, and refining follows a global context.

Technology coverage: Conventional market technology is used.

Precision and completeness: The dataset can be considered complete, with emissions reported for every unit process. This aspect is further addressed in the uncertainty analysis.

Representativeness: The system is representative of the intended geography and technology. Milling data are derived from the U.S. context and may not represent global practices; thus, milling would be a source of uncertainty. However, milling and refining are general processes, with the main variation being the oil content of the seed, which is taken into consideration. This aspect is further addressed in the uncertainty analysis.
Consistency and reproducibility: The data gathered all follow the same approach as performed by Ecoinvent; therefore, the same datasets can be accessed by other LCA practitioners, making the results reproducible. Any changes to the original datasets are documented in this study.

Data sources: All datasets for this system were gathered from Ecoinvent. However, the underlying data were derived from on-site data collection and literature sources. Any extrapolations done in the original dataset are reflected in the data quality coefficients used in uncertainty estimation.

\section{Data Quality For Canola (U.S.)}

Temporal coverage: The temporal coverage for cultivation is 2001 to 2018. Milling has a temporal coverage of 1996 to 2003 , and refining has a temporal coverage of 2012 to 2017.

Geographical coverage: Cultivation of rapeseed is modeled according to a U.S. context. Milling and refining are modeled after the rest of the world, but electricity for these processes was modified to U.S. average electricity to approximate the intended geography.

Technology coverage: Cultivation represents conventional technology for the U.S. Milling is based on canola crude processing, and refining is based on soybean refining systems.

Precision and completeness: The dataset can be considered complete, with emissions reported for every unit process. This aspect is further addressed in the uncertainty analysis.

Representativeness: The system is representative of the intended geography and technology. Refining data are based on soybean systems. However, refining is a general process, with the main variation being the oil content of the seed, which is taken into consideration. This aspect is further addressed in the uncertainty analysis.

Consistency and reproducibility: The data gathered all follow the same approach as performed by Ecoinvent; therefore, the same datasets can be accessed by other LCA practitioners, making the results reproducible. Any changes to the original datasets are documented in this study.

Data sources: All datasets for this system were gathered from Ecoinvent. However, the underlying data sources were derived from on-site data collection and literature sources. For instance, canola cultivation is based on U.S. data from the National Renewable Energy Laboratory (NREL), surveys, and expert knowledge. Milling is based on typical canola mill operation in the EU, and refining is based on soybean systems. Any extrapolations done in the original dataset are reflected in the data quality coefficients used in uncertainty estimation. 
APPENDIX D MidPoint and Contribution AnAlysis Data TABles
AND Allocation SENSITIVITy ANALYSIS

Table D1. Data of contribution plot for refined CSO (U.S.).

\begin{tabular}{cccc}
\hline Impact Category & $\begin{array}{c}\text { Cultivation } \\
(\%)\end{array}$ & $\begin{array}{c}\text { Milling } \\
(\%)\end{array}$ & $\begin{array}{c}\text { Refining } \\
(\%)\end{array}$ \\
\hline Global warming & 68.37 & 12.24 & 19.39 \\
Abiotic depletion & 83.28 & 4.98 & 11.75 \\
Eutrophication & 86.19 & 3.69 & 10.11 \\
Acidification & 81.53 & 9.53 & 8.93 \\
Photochemical oxidation & 38.39 & 46.50 & 15.11 \\
Fine particulate matter & 72.59 & 12.64 & 14.77 \\
Ozone layer depletion & 58.91 & 9.94 & 31.15 \\
Water scarcity & 92.99 & 0.05 & 6.96 \\
\hline
\end{tabular}

Table D2. Data of contribution plot for refined palm (ID and MY).

\begin{tabular}{cccc}
\hline Impact Category & $\begin{array}{c}\text { Cultivation } \\
(\%)\end{array}$ & $\begin{array}{c}\text { Milling } \\
(\%)\end{array}$ & $\begin{array}{c}\text { Refining } \\
(\%)\end{array}$ \\
\hline Global warming & 94.29 & 0.59 & 5.12 \\
Abiotic depletion & 73.87 & 7.83 & 18.29 \\
Eutrophication & 90.68 & 2.01 & 7.30 \\
Acidification & 82.36 & 7.38 & 10.26 \\
Photochemical oxidation & 58.28 & 39.69 & 2.02 \\
Fine particulate matter & 80.31 & 12.40 & 7.29 \\
Ozone layer depletion & 47.31 & 5.59 & 47.10 \\
Water scarcity & 54.81 & 8.00 & 37.20 \\
\hline
\end{tabular}

Table D3. Data of contribution plot for refined soybean (GLO).

\begin{tabular}{cccc}
\hline Impact Category & $\begin{array}{c}\text { Cultivation } \\
(\%)\end{array}$ & $\begin{array}{c}\text { Milling } \\
(\%)\end{array}$ & $\begin{array}{c}\text { Refining } \\
(\%)\end{array}$ \\
\hline Global warming & 93.20 & 3.33 & 3.48 \\
Abiotic depletion & 78.89 & 8.22 & 12.89 \\
Eutrophication & 81.75 & 2.29 & 15.96 \\
Acidification & 72.52 & 13.68 & 13.80 \\
Photochemical oxidation & 66.89 & 31.34 & 1.77 \\
Fine particulate matter & 88.19 & 5.21 & 6.60 \\
Ozone layer depletion & 48.58 & 34.76 & 16.66 \\
Water scarcity & 44.44 & 0.82 & 54.74 \\
\hline
\end{tabular}

Table D4. Data of contribution plot for refined canola (U.S.).

\begin{tabular}{cccc}
\hline Impact Category & $\begin{array}{c}\text { Cultivation } \\
(\%)\end{array}$ & $\begin{array}{c}\text { Milling } \\
(\%)\end{array}$ & $\begin{array}{c}\text { Refining } \\
(\%)\end{array}$ \\
\hline Global warming & 91.92 & 2.73 & 5.35 \\
Abiotic depletion & 94.92 & 1.40 & 3.68 \\
Eutrophication & 95.97 & 0.51 & 3.53 \\
Acidification & 96.06 & 1.31 & 2.64 \\
Photochemical oxidation & 69.58 & 23.83 & 6.59 \\
Fine particulate matter & 91.87 & 2.84 & 5.29 \\
Ozone layer depletion & 87.02 & 1.74 & 11.24 \\
Water scarcity & 65.00 & 0.22 & 34.78 \\
\hline
\end{tabular}

Table D6. Percent change of impact from economic to mass allocation.

\begin{tabular}{ccccc}
\hline & $\begin{array}{c}\text { Refined } \\
\text { CSO } \\
\text { (U.S.) }\end{array}$ & $\begin{array}{c}\text { Palm } \\
\text { (ID and } \\
\text { MY) }\end{array}$ & $\begin{array}{c}\text { Soybean } \\
\text { (GLO) }\end{array}$ & $\begin{array}{c}\text { Canola } \\
\text { (U.S.) }\end{array}$ \\
\hline Global warming & $34 \%$ & $-6 \%$ & $-70 \%$ & $-45 \%$ \\
Abiotic depletion & $47 \%$ & $-5 \%$ & $-64 \%$ & $-45 \%$ \\
Eutrophication & $50 \%$ & $-6 \%$ & $-59 \%$ & $-46 \%$ \\
Acidification & $43 \%$ & $-6 \%$ & $-62 \%$ & $-46 \%$ \\
Photochemical oxidation & $-3 \%$ & $-6 \%$ & $-71 \%$ & $-44 \%$ \\
Fine particulate matter & $36 \%$ & $-6 \%$ & $-67 \%$ & $-45 \%$ \\
Ozone layer depletion & $30 \%$ & $-3 \%$ & $-60 \%$ & $-42 \%$ \\
Water scarcity & $56 \%$ & $-3 \%$ & $225 \%$ & $-31 \%$ \\
\hline
\end{tabular}

Table D7. Alternative economic partitioning coefficients and percent changes corresponding to baseline values.

\begin{tabular}{lcccc}
\hline & \multicolumn{4}{c}{ Partitioning Coefficients $\left(\$ \mathrm{~kg}^{-1}\right)$} \\
\cline { 2 - 5 } & CSO & Soybean & Palm & Canola \\
\hline Baseline values & & & & \\
Crude oil & 1.04 & 1.22 & 0.36 & 0.53 \\
Meal & 0.25 & 0.12 & 0.06 & 0.13 \\
Crude oil to meal ratio & 4.16 & 9.88 & 5.93 & 4.17 \\
$\quad$ Oil partitioning factor & 0.58 & 0.70 & 0.85 & 0.72 \\
\hline Alternative values (three-year trend) & & & \\
Crude oil & 1.14 & 0.79 & 0.65 & 0.97 \\
Meal & 0.29 & 0.37 & 0.15 & 0.35 \\
Crude oil to meal ratio & 3.93 & 2.15 & 4.32 & 2.76 \\
Oil partitioning factor & 0.57 & 0.34 & 0.94 & 0.63 \\
\hline Change in partitioning & $-2.21 \%$ & $-52.04 \%$ & $10.44 \%$ & $-12.69 \%$ \\
coefficient at milling & & & & \\
\hline
\end{tabular}

The market prices for soybean (GLO) crude oil and meal represent a three-year global average (Index Mundi, 2020), as do those for palm crude oil (Index Mundi, 2020). Palm kernel meal prices were gathered from FAO (2019). Canola crude oil and meal market prices were gathered from the Canola Council of Canada for 2017-2019 (Canada, 2019). Market prices for cottonseed crude oil and meal were estimated based on global averages for 2019 (Hughes, 2019). Application of these new prices changed the partitioning coefficient for the milling phase by less than 13\% for three of the four oil systems (table D7), meaning that the partitioning coefficients can be considered stable, except for the soybean system for which the partitioning coefficient was reduced by half when using the alternate economic data (table D7).

Table D5. Data of comparative results for vegetable frying oils (1 $\mathrm{kg}$ of refined oil).

\begin{tabular}{|c|c|c|c|c|c|c|c|c|c|}
\hline Impact Category & Unit & $\begin{array}{c}\text { Refined CSO } \\
\text { (U.S.) }\end{array}$ & $\begin{array}{c}\text { Palm } \\
\text { (ID and MY) }\end{array}$ & $\begin{array}{c}\text { Soybean } \\
\text { (GLO) }\end{array}$ & $\begin{array}{c}\text { Canola } \\
\text { (U.S.) }\end{array}$ & $\begin{array}{l}\mathrm{CSO} / \\
\mathrm{Palm}\end{array}$ & $\begin{array}{c}\text { Canola/ } \\
\text { Corn/Soy }\end{array}$ & $\begin{array}{l}\text { Soy/Corn/ } \\
\text { CSO }\end{array}$ & $\begin{array}{l}\text { Canola/ } \\
\text { Palm }\end{array}$ \\
\hline Global warming & $\mathrm{kg} \mathrm{CO}$-eq & $1.06 \mathrm{E}+00$ & $4.83 \mathrm{E}+00$ & $6.42 \mathrm{E}+00$ & $3.82 \mathrm{E}+00$ & $2.94 \mathrm{E}+00$ & $4.76 \mathrm{E}+00$ & $3.82 \mathrm{E}+00$ & $4.33 \mathrm{E}+00$ \\
\hline Abiotic depletion & kg Sb-eq & $4.40 \mathrm{E}-06$ & $3.58 \mathrm{E}-06$ & $4.39 \mathrm{E}-06$ & $1.41 \mathrm{E}-05$ & $3.99 \mathrm{E}-06$ & $1.05 \mathrm{E}-05$ & $7.23 \mathrm{E}-06$ & $8.82 \mathrm{E}-06$ \\
\hline Eutrophication & $\mathrm{kgPO}_{4}-\mathrm{eq}$ & $1.30 \mathrm{E}-02$ & $1.85 \mathrm{E}-02$ & $1.07 \mathrm{E}-02$ & $3.72 \mathrm{E}-02$ & $1.57 \mathrm{E}-02$ & $2.10 \mathrm{E}-02$ & $1.30 \mathrm{E}-02$ & $2.78 \mathrm{E}-02$ \\
\hline Acidification & $\mathrm{kg} \mathrm{SO}_{2}$-eq & $9.83 \mathrm{E}-03$ & $1.13 \mathrm{E}-02$ & $7.57 \mathrm{E}-03$ & $3.33 \mathrm{E}-02$ & $1.05 \mathrm{E}-02$ & $2.21 \mathrm{E}-02$ & $1.42 \mathrm{E}-02$ & $2.23 \mathrm{E}-02$ \\
\hline Photochemical oxidation & $\mathrm{kg} \mathrm{C}_{2} \mathrm{H}_{4}$-eq & $3.53 \mathrm{E}-04$ & $3.30 \mathrm{E}-03$ & $3.48 \mathrm{E}-03$ & $8.09 \mathrm{E}-04$ & $1.83 \mathrm{E}-03$ & $1.76 \mathrm{E}-03$ & $1.60 \mathrm{E}-03$ & $2.06 \mathrm{E}-03$ \\
\hline Fine particulate matter & $\mathrm{kg} \mathrm{PM}_{2.5}$-eq & $2.93 \mathrm{E}-03$ & $6.62 \mathrm{E}-03$ & $6.28 \mathrm{E}-03$ & $8.19 \mathrm{E}-03$ & $4.78 \mathrm{E}-03$ & $7.76 \mathrm{E}-03$ & $5.97 \mathrm{E}-03$ & $7.40 \mathrm{E}-03$ \\
\hline Ozone layer depletion & kg CFC-11-eq & $1.00 \mathrm{E}-07$ & $7.30 \mathrm{E}-08$ & $1.15 \mathrm{E}-07$ & $2.78 \mathrm{E}-07$ & $8.67 \mathrm{E}-08$ & $2.33 \mathrm{E}-07$ & $1.72 \mathrm{E}-07$ & $1.76 \mathrm{E}-07$ \\
\hline Water scarcity & $\mathrm{m}^{3}$ & $4.83 \mathrm{E}+01$ & $5.07 \mathrm{E}+00$ & $6.40 \mathrm{E}-02$ & $9.66 \mathrm{E}+00$ & $2.67 \mathrm{E}+01$ & $1.12 \mathrm{E}+01$ & $2.42 \mathrm{E}+01$ & $7.37 \mathrm{E}+00$ \\
\hline
\end{tabular}




\section{APPENDIX E}

\section{Trade-Off Evaluation of Frying OIls}

We performed an evaluation of tradeoffs that considered the uncertainty propagated in each oil system to aid in the interpretation of tradeoffs in the comparative analysis. The approach was based on the use of the overlap area of alternatives (Prado-Lopez et al., 2016) to evaluate the similarity of alternatives. That is, when the probability distributions of alternatives overlap so that the overlapping area is close to a value of 1 (the area under each distribution is 1), then the alternatives are very similar and a given decision for an impact category has little or no effect on the outcome for that impact category. Where the performances of alternatives are different and have less overlap, the selection of an alternative becomes more relevant for that impact category. This approach lists the impact categories according to the size of the average overlap area. The impact categories at the top of the list have a higher relevance to the selection.

Comparison of the four frying oils showed that refined CSO (U.S.) was among the top two alternatives for the five impact categories that were considered most relevant to the selection (table E1). Overall, refined CSO (U.S.) was among the top two alternatives for six of the eight impact categories evaluated. The closest alternative was soybean (GLO), which was among the top two for five of the eight categories. However, when evaluating the performance of soybean (GLO) relative to uncertainty, its favorable performance tended to be in the bottom half of table E1, i.e., where there is greater uncertainty. Although a final oil selection depends on the weighting applied to the different impact categories, this analysis shows how refined CSO (U.S.) appears to be an effective compromise, given its favorable performance in most impact categories.

Table E1. Order of impact categories according to mean overlap area and top two oils per impact category.

\begin{tabular}{clcc}
\hline \multicolumn{1}{c}{ Impact Category } & $\begin{array}{c}\text { Mean } \\
\text { Overlap } \\
\text { Area }\end{array}$ & $\begin{array}{c}\text { Top Two Oils per Impact } \\
\text { Category According to } \\
\text { Mean Performance }\end{array}$ \\
\hline 1 & Global warming & 0.02 & CSO and canola \\
2 & Acidification & 0.03 & Soybean and CSO \\
5 & Eutrophication & 0.11 & Soybean and CSO \\
6 & Photochemical oxidation & 0.12 & CSO and canola \\
7 & Fine particulate matter & 0.14 & CSO and soybean \\
8 & Water scarcity & 0.16 & Soybean and palm \\
9 & Abiotic depletion & 0.19 & Palm and soybean \\
10 & Ozone layer depletion & 0.24 & Palm and CSO \\
\hline
\end{tabular}

